Prepared in cooperation with the Kansas Water Office

Potentiometric Surfaces in the Springfield Plateau and Ozark Aquifers of Northwestern Arkansas, Southeastern Kansas, Southwestern Missouri, and Northeastern Oklahoma, 2006

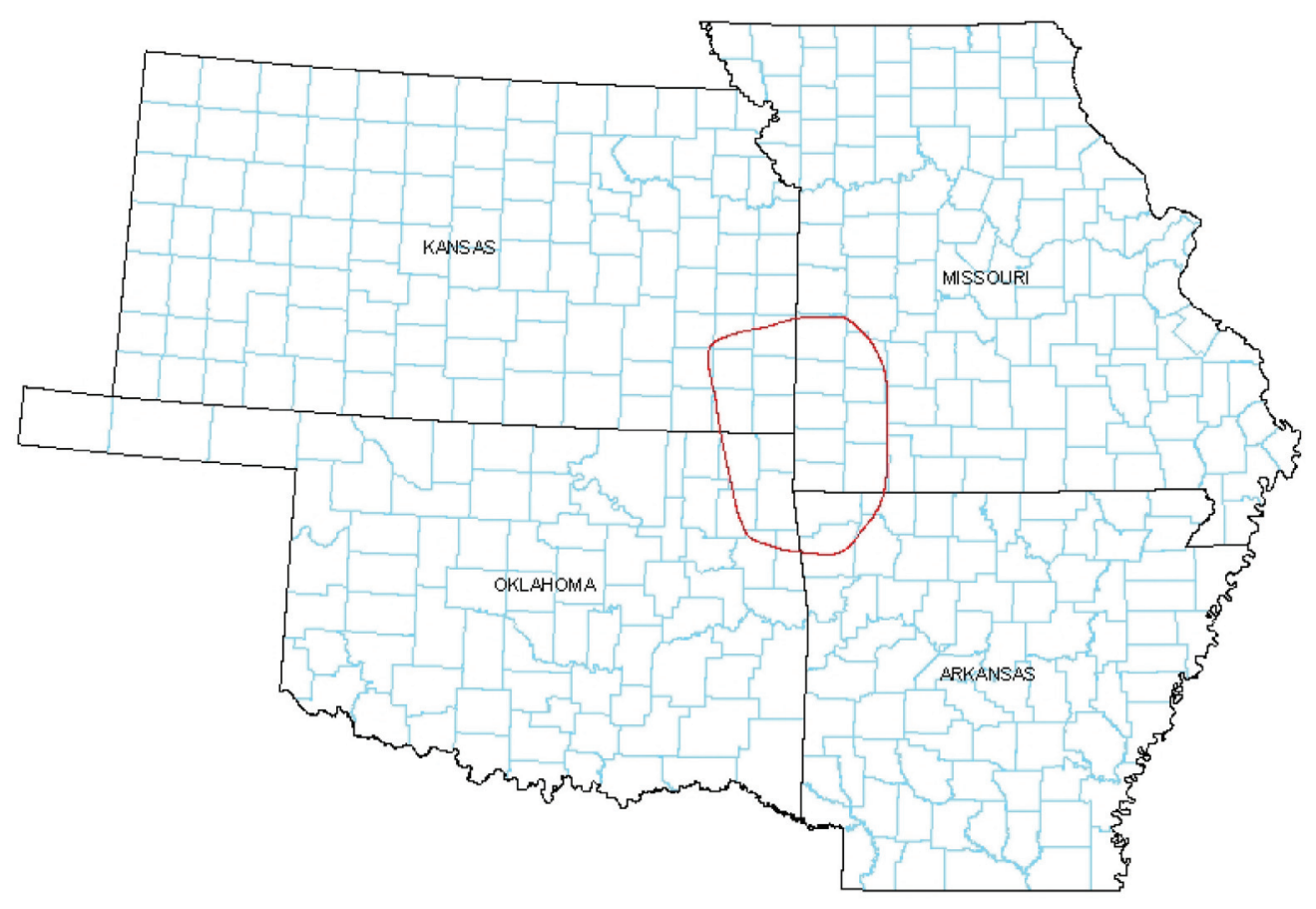

Scientific Investigations Report 2007-5253 


\section{Potentiometric Surfaces in the Springfield Plateau and Ozark Aquifers of Northwestern Arkansas, Southeastern Kansas, Southwestern Missouri, and Northeastern Oklahoma, 2006}

By Jonathan A. Gillip, John B. Czarnecki, and Douglas N. Mugel

Prepared in cooperation with the Kansas Water Office

Scientific Investigations Report 2007-5253 


\section{U.S. Department of the Interior DIRK KEMPTHORNE, Secretary}

\section{U.S. Geological Survey \\ Mark D. Myers, Director}

\section{U.S. Geological Survey, Reston, Virginia: 2008}

For product and ordering information:

World Wide Web: http://www.usgs.gov/pubprod

Telephone: 1-888-ASK-USGS

For more information on the USGS--the Federal source for science about the Earth, its natural and living resources, natural hazards, and the environment:

World Wide Web: http://www.usgs.gov

Telephone: 1-888-ASK-USGS

Any use of trade, product, or firm names is for descriptive purposes only and does not imply endorsement by the U.S. Government.

Although this report is in the public domain, permission must be secured from the individual copyright owners to reproduce any copyrighted materials contained within this report.

Suggested citation:

Gillip, J.A., Czarnecki, J.B., and Mugel, D.N., 2008, Potentiometric surfaces in the Springfield Plateau and Ozark aquifers of northwestern Arkansas, southeastern Kansas, southwestern Missouri, and northeastern Oklahoma, 2006: U.S. Geological Survey Scientific Investigations Report 2007-5253, 25 p. 


\section{Contents}

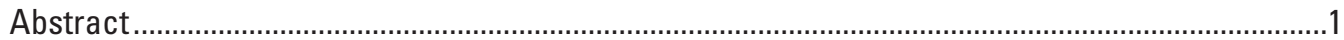

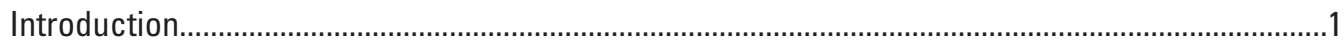

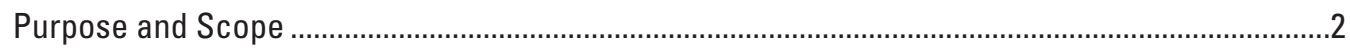

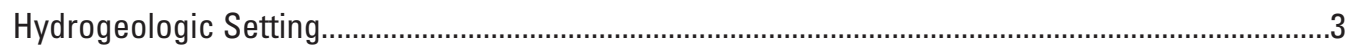

Springfield Plateau Aquifer .................................................................................................

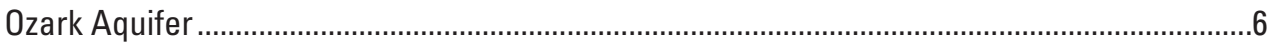

Potentiometric-Surface Construction Methods ……………........................................................

Potentiometric Surfaces....................................................................................................

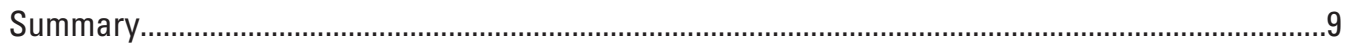

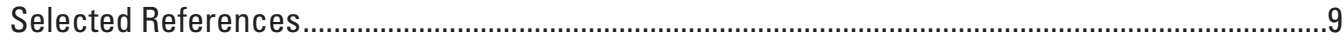

Appendix 1. Information pertaining to wells completed in the Springfield Plateau aquifer ..........13

Appendix 2. Information pertaining to wells completed in the Ozark aquifer ................................17

Appendix 3. Information pertaining to springs in the Springfield Plateau aquifer .........................23

Appendix 4. Information pertaining to springs in the Ozark aquife R ...........................................25

\section{Plates}

[End of report]

1. Map showing potentiometric surface of the Springfield Plateau aquifer in northwestern Arkansas, southeastern Kansas, southwestern Missouri, and northeastern Oklahoma, 2006

2. Map showing potentiometric surface of the Ozark aquifer in northwestern Arkansas, southeastern Kansas, southwestern Missouri, and northeastern Oklahoma, 2006

\section{Figures}

1. Map showing physiographic subdivisions of the Ozark Plateaus Province and adjacent areas..... .2

2. Generalized hydrogeologic section of the Ozark Plateaus aquifer system and adjacent hydrogeologic units

\section{Tables}

1. General correlation of hydrogeologic units of the Springfield Plateau aquifer, the Ozark confining unit, the Ozark aquifer, and the St. Francois confining unit 


\section{Conversion Factors and Datums}

\begin{tabular}{lcl}
\hline \multicolumn{1}{c}{ Multiply } & By & \multicolumn{1}{c}{ To obtain } \\
\hline & Length & \\
\hline foot $(\mathrm{ft})$ & 0.3048 & meter $(\mathrm{m})$ \\
mile $(\mathrm{mi})$ & 1.609 & kilometer $(\mathrm{km})$ \\
foot per mile $(\mathrm{ft} / \mathrm{mi})$ & 0.1894 & meters per kilometer $(\mathrm{m} / \mathrm{km})$ \\
\hline & Area & \\
\hline square mile $\left(\mathrm{mi}^{2}\right)$ & 2.590 & square kilometer $\left(\mathrm{km}^{2}\right)$ \\
\hline & Flow rate & \\
\hline foot per day $(\mathrm{ft} / \mathrm{d})$ & 0.3048 & meter per day $(\mathrm{m} / \mathrm{d})$ \\
gallon per minute $(\mathrm{gal} / \mathrm{m})$ & 0.6308 & liter per second $(\mathrm{L} / \mathrm{s})$ \\
\hline
\end{tabular}

Altitude, as used in this report, refers to distance above the vertical datum, and is referenced to the National Geodetic Vertical Datum of 1929 (NGVD of 1929).

Latitude and longitude are referenced to the North American Datum of 1983 (NAD of 1983). 


\title{
Potentiometric Surfaces in the Springfield Plateau and Ozark Aquifers of Northwestern Arkansas, Southeastern Kansas, Southwestern Missouri, and Northeastern Oklahoma, 2006
}

\author{
By Jonathan A. Gillip, John B. Czarnecki, and Douglas N. Mugel
}

\section{Abstract}

The Springfield Plateau and Ozark aquifers are important sources of ground water in the Ozark Plateaus aquifer system. Water from these aquifers is used for agricultural, domestic, industrial, and municipal water sources. Changing water use over time in these aquifers presents a need for updated potentiometric-surface maps of the Springfield Plateau and Ozark aquifers.

The Springfield Plateau aquifer consists of water-bearing Mississippian-age limestone and chert. The Ozark aquifer consists of Late Cambrian to Middle Devonian age water-bearing rocks consisting of dolostone, limestone, and sandstone. Both aquifers are complex with areally varying lithologies, discrete hydrologic units, varying permeabilities, and secondary permeabilities related to fractures and karst features.

During the spring of 2006, ground-water levels were measured in 285 wells. These data, and water levels from selected lakes, rivers, and springs, were used to create potentiometric-surface maps for the Springfield Plateau and Ozark aquifers. Linear kriging was used initially to construct the water-level contours on the maps; the contours were subsequently modified using hydrologic judgment. The potentiometric-surface maps presented in this report represent groundwater conditions during the spring of 2006. During the spring of 2006, the region received less than average rainfall. Dry conditions prior to the spring of 2006 could have contributed to the observed water levels as well.

The potentiometric-surface map of the Springfield Plateau aquifer shows a maximum measured water-level altitude within the study area of about 1,450 feet at a spring in Barry County, Missouri, and a minimum measured water-level altitude of 579 feet at a well in Ottawa County, Oklahoma. Cones of depression occur in Dade, Lawrence and Newton Counties in Missouri and Delaware and Ottawa Counties in Oklahoma. These cones of depression are associated with private wells. Ground water in the Springfield Plateau aquifer generally flows to the west in the study area, and to surface features (lakes, rivers, and springs) particularly in the south and east of the study area where the Springfield Plateau aquifer is closest to land surface.

The potentiometric-surface map of the Ozark aquifer indicates a maximum measured water-level altitude of 1,303 feet in the study area at a well in Washington County, Arkansas, and a minimum measured water-level altitude of 390 feet in Ottawa County, Oklahoma. The water in the Ozark aquifer generally flows to the northwest in the northern part of the study area and to the west in the remaining study area. Cones of depression occur in Barry, Barton, Cedar, Jasper, Lawrence, McDonald, Newton, and Vernon Counties in Missouri, Cherokee and Crawford Counties in Kansas, and Craig and Ottawa Counties in Oklahoma. These cones of depression are associated with municipal supply wells. The flow directions, based on both potentiometric-surface maps, generally agree with flow directions indicated by previous studies.

\section{Introduction}

The Springfield Plateau and Ozark aquifers are important sources of ground water in the Ozark Plateaus Province (fig. 1). The Springfield Plateau aquifer is an important source of ground water primarily for domestic and agricultural use. The Ozark aquifer is the primary source of ground water in the Ozark Plateaus Province (Fennemen and Johnson, 1946), which includes parts of Arkansas, Kansas, Missouri, and Oklahoma (fig. 1), supplying water for municipal, agricultural, industrial, and private use.

In Arkansas, the amount of water withdrawn from the Ozark aquifer increased steadily through the 1990's but began to decline by 2000 (Holland, 1987, 1993, 1999, 2004) as municipal supply wells were abandoned in favor of surfacewater impoundments. In addition, many domestic wells were abandoned as municipal water became available in rural areas. In Kansas, water use has shifted to the Ozark aquifer as concerns with contamination of the Springfield Plateau aquifer 
have resulted in a court order for the development of rural water districts (Iona Branscum, Kansas Water Office, written commun., 2007). Missouri relies heavily on the Ozark aquifer for municipal supply but the Springfield Plateau aquifer also is widely used. In Oklahoma, the Springfield Plateau aquifer and to a greater extent the Ozark aquifer continue to be used for municipal, agricultural, and domestic supplies. Water-use changes and future water-availability questions in these aquifers present a need for updated potentiometric-surface maps of the Springfield Plateau and Ozark aquifers.

The U. S. Geological Survey (USGS) in cooperation with the Kansas Water Office (and supported in part by Kansas State Water Plan) conducted a study in 2006 of the potentiometric surfaces of the Springfield Plateau and Ozark aquifers as part of a water availability investigation in a study area con- taining parts of northwestern Arkansas, southeastern Kansas, southwestern Missouri, and northeastern Oklahoma (fig. 1). The study area covers approximately 12,700 square miles.

\section{Purpose and Scope}

The purpose of this report is to describe the potentiometric-surface maps of the Springfield Plateau and Ozark aquifers in the study area representing conditions during the spring of 2006. The potentiometric-surface maps presented in this report allow comparison to water levels presented by previous investigators and provide a baseline to compare future changes in water levels in the study area. The potentiometric surfaces

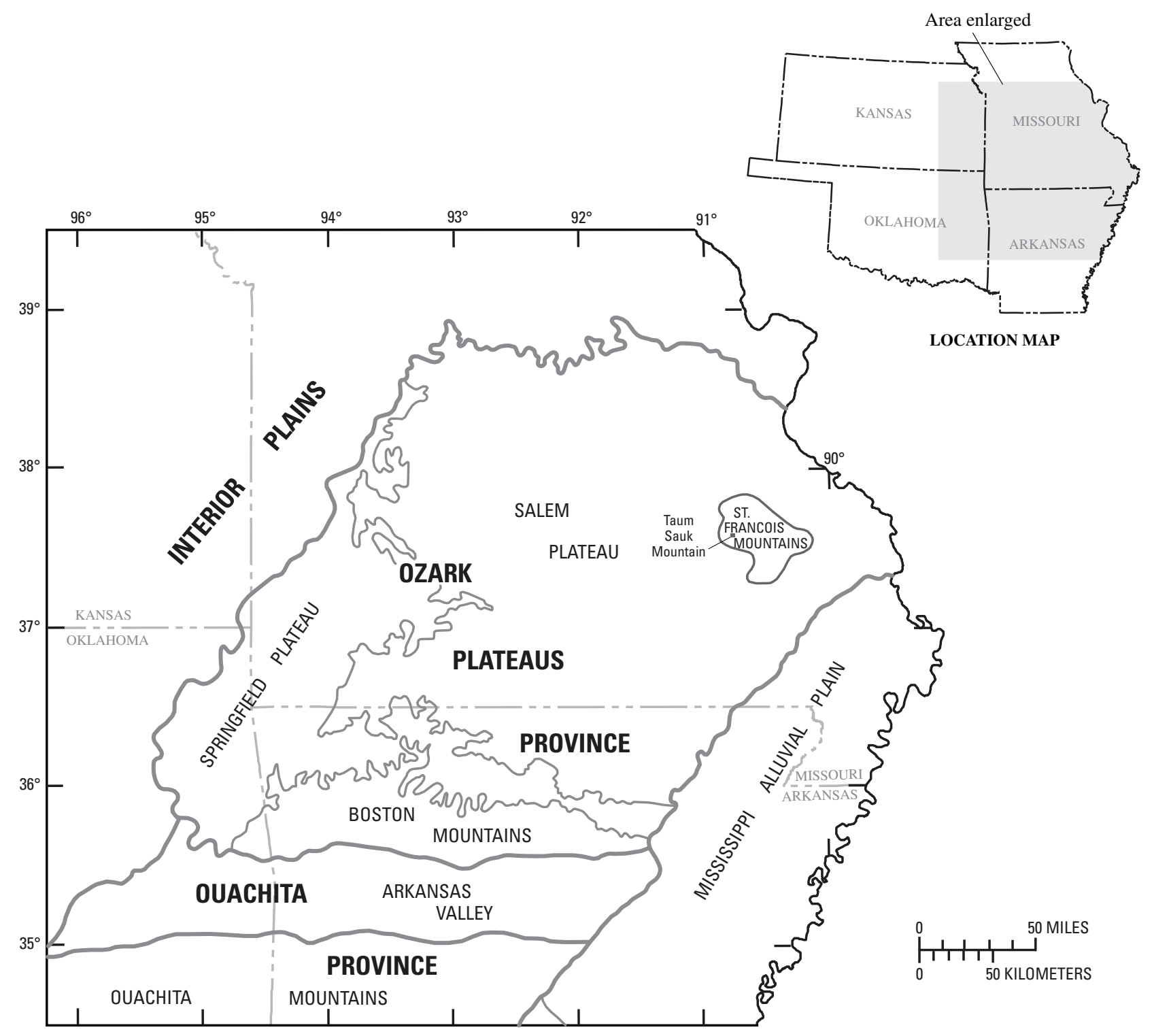

Figure 1. Physiographic subdivsions of the Ozark Plateaus Province and adjacent areas (modified from Imes and Emmett, 1994). 
and water-level measurements are necessary components for constructing ground-water flow models that can be used to simulate ground-water flow in the Springfield Plateau and Ozark aquifers.

The potentiometric-surface maps presented in this report are the first potentiometric surfaces created from recent (2006) data for the Springfield Plateau and Ozark aquifers over the study area. A potentiometric surface of the Ozark aquifer in northern Arkansas was created from 2004 data (Schrader, 2005). Macfarlane and Hathaway (1987) presented a potentiometric-surface map for the Ozark aquifer in the tristate region of Kansas, Missouri, and Oklahoma for conditions representing the period 1979 to 1981. Predevelopment potentiometric surfaces for the Springfield Plateau and Ozark aquifers were approximated using a ground-water flow model with no water use specified, to simulate conditions without any human impact (Imes and Emmett, 1994, figs. 28 and 40). The potentiometric-surface maps presented in this report lie within the boundaries of the potentiometric-surface maps created by Imes and Emmet (1994) and cover a larger area than the potentiometric-surface map constructed by Macfarlane and Hathaway (1987).

To create the potentiometric-surface maps, water levels were collected in 285 wells completed in the Springfield Plateau and Ozark aquifers during the spring of 2006. Waterlevel data were collected by the USGS in Arkansas, Kansas, Missouri, and Oklahoma, as well as by the Kansas Geological Survey and the Missouri Department of Natural Resources. For the Springfield Plateau aquifer potentiometric-surface map, the altitude of lakes, rivers, and streams was used as additional water-level control points where the Springfield Plateau aquifer outcrops at land surface because the aquifer is in hydrogeologic connection with those surface-water bodies. The altitude of four springs also was used for the construction of the Ozark aquifer potentiometric surface.

\section{Hydrogeologic Setting}

The Springfield Plateau and Ozark aquifers are part of the Ozark Plateaus aquifer system, which is divided into five primary hydrogeologic units (Imes and Emmett, 1994; Jorgensen and others, 1996). The units can be distinguished by rocks with similar hydrologic properties, although the boundaries of the units do not always coincide with formation boundaries, and can span several geologic time systems. The geologic formations that make up the Ozark Plateaus aquifer system range from Cambrian to Mississippian age. The five major hydrogeologic units from youngest to oldest are: the Springfield Plateau aquifer, the Ozark confining unit, the Ozark aquifer, the St. Francois confining unit, and the St. Francois aquifer (fig. 2). The general correlation of the Springfield Plateau aquifer, the Ozark confining unit, and the Ozark aquifer are shown in table 1. The Western Interior Plains confining unit, consisting of less permeable hydrogeologic units of Mississip- pian to Pennsylvanian age, overlies the Ozark Plateaus aquifer system. The Precambrian basement confining unit underlies the Ozark Plateaus aquifer system. These hydrogeologic units and their members are discussed in detail in Imes and Emmett (1994). A brief discussion of the characteristics of the Springfield Plateau aquifer and the Ozark aquifer follows.

\section{Springfield Plateau Aquifer}

The Springfield Plateau aquifer is the uppermost hydrogeologic unit in the Ozark Plateaus aquifer system. The formations of the Springfield Plateau aquifer outcrop over much of the study area (fig. 2). There are small areas in Benton and Carroll Counties in Arkansas; Barry, Cedar, Christian, Dade, Green, McDonald, Newton, Polk, St. Clair, and Stone Counties in Missouri; and Adair, Cherokee, and Delaware Counties in Oklahoma where the Springfield Plateau aquifer is absent. The Springfield Plateau aquifer is overlain by the Western Interior Plains confining system in the western part of the study area and underlain by the Ozark confining unit.

The Springfield Plateau aquifer outcrops over the Springfield Plateau physiographic section, which consists of about one-third of the surface area of the Ozark Plateaus aquifer system. In the northern part of the Ozark Plateaus aquifer system, the Springfield Plateau aquifer dips gently to the northwest. West of the Springfield Plateau section, the aquifer is buried by the less permeable units of the Western Interior Plains confining system to a depth of up to $500 \mathrm{ft}$ in southeastern Kansas and as much as 4,000 ft in Oklahoma near the Arkansas Valley. In Arkansas, the southward dip of the Springfield Plateau aquifer can exceed $200 \mathrm{ft} / \mathrm{mi}$ and the depth of burial exceeds $5,000 \mathrm{ft}$ in the Arkansas Valley (Imes and Emmett, 1994).

The thickness of the Springfield Plateau aquifer ranges from 0 to more than $400 \mathrm{ft}$ in the northwestern part of the study area. The aquifer generally is thicker in southeastern Kansas, southwestern Missouri, and northeastern Oklahoma. The thickness of the aquifer in northern Arkansas is less than $400 \mathrm{ft}$ (Imes and Emmett, 1994).

The Springfield Plateau aquifer consists mainly of coarsely crystalline Mississippian age limestones with local high-percentage occurrences of chert. Dissolution of limestone leads to karst features, such as caves, sinkholes, and solutional channels along fractures. These karst features may result in a large secondary permeability, that is, permeability developed by the dissolution of carbonate rock along fractures and bedding planes. Springs are common where the Boone Formation and the St. Joe Limestone outcrop in Arkansas. The Springfield Plateau aquifer is anisotropic and heterogeneous. The average horizontal hydraulic conductivity is estimated to be $22 \mathrm{ft} / \mathrm{d}$ (Imes and Emmett, 1994). Wells completed in the Springfield Plateau aquifer typically produce less than $20 \mathrm{gal} / \mathrm{min}$, although some industrial wells completed in this aquifer in southwestern Missouri yield up to $400 \mathrm{gal} /$ min (Adamski and others, 1995). The Springfield Plateau aquifer receives recharge from its outcrop area and is uncon- 


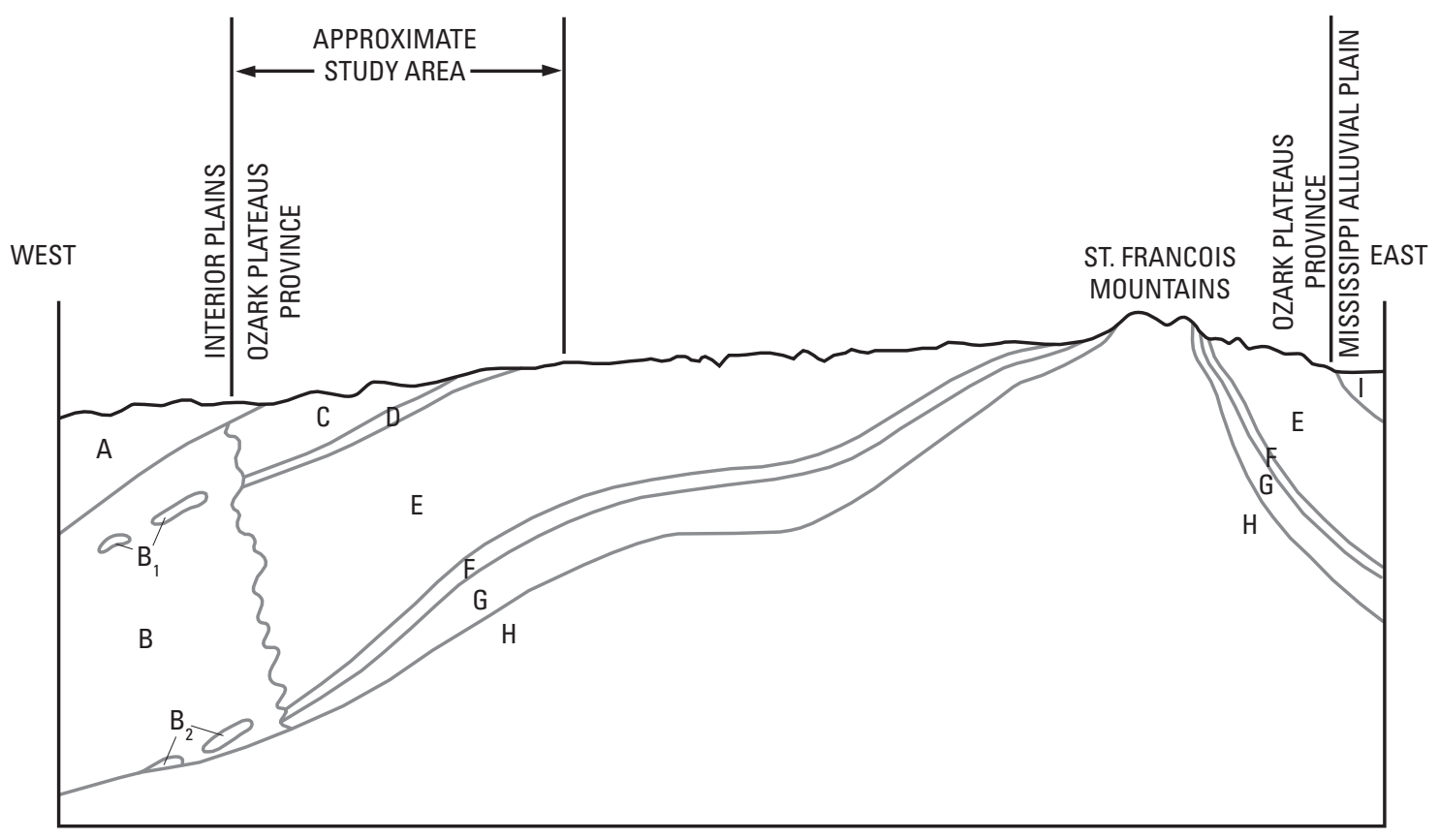

EXPLANATION

A WESTERN INTERIOR PLAINS CONFINING SYSTEM

WESTERN INTERIOR PLAINS AQUIFER SYSTEM

STRATIGRAPHICALLY EQUIVALENT TO OZARK CONFINING UNIT

$\mathrm{B}_{2}$ STRATIGRAPHICALLY EQUIVALENT TO ST. FRANCOIS CONFINING UNIT

OZARK PLATEAUS AQUIFER SYSTEM

C SPRINGFIELD PLATEAU AQUIFER

OZARK CONFINING UNIT

OZARK AQUIFER

ST. FRANCOIS CONFINING UNIT

ST. FRANCOIS AQUIFER

BASEMENT CONFINING UNIT

POST-PALEOZOIC SEDIMENTS

Figure 2. Generalized hydrogeologic section of the Ozark Plateaus aquifer system and adjacent hydrogeologic units (from Imes and Emmett, 1994). 
Table 1. General correlation of hydrogeologic units of the Springfield Plateau aquifer, the Ozark confining unit, the Ozark aquifer, and the St. Francois confining unit.

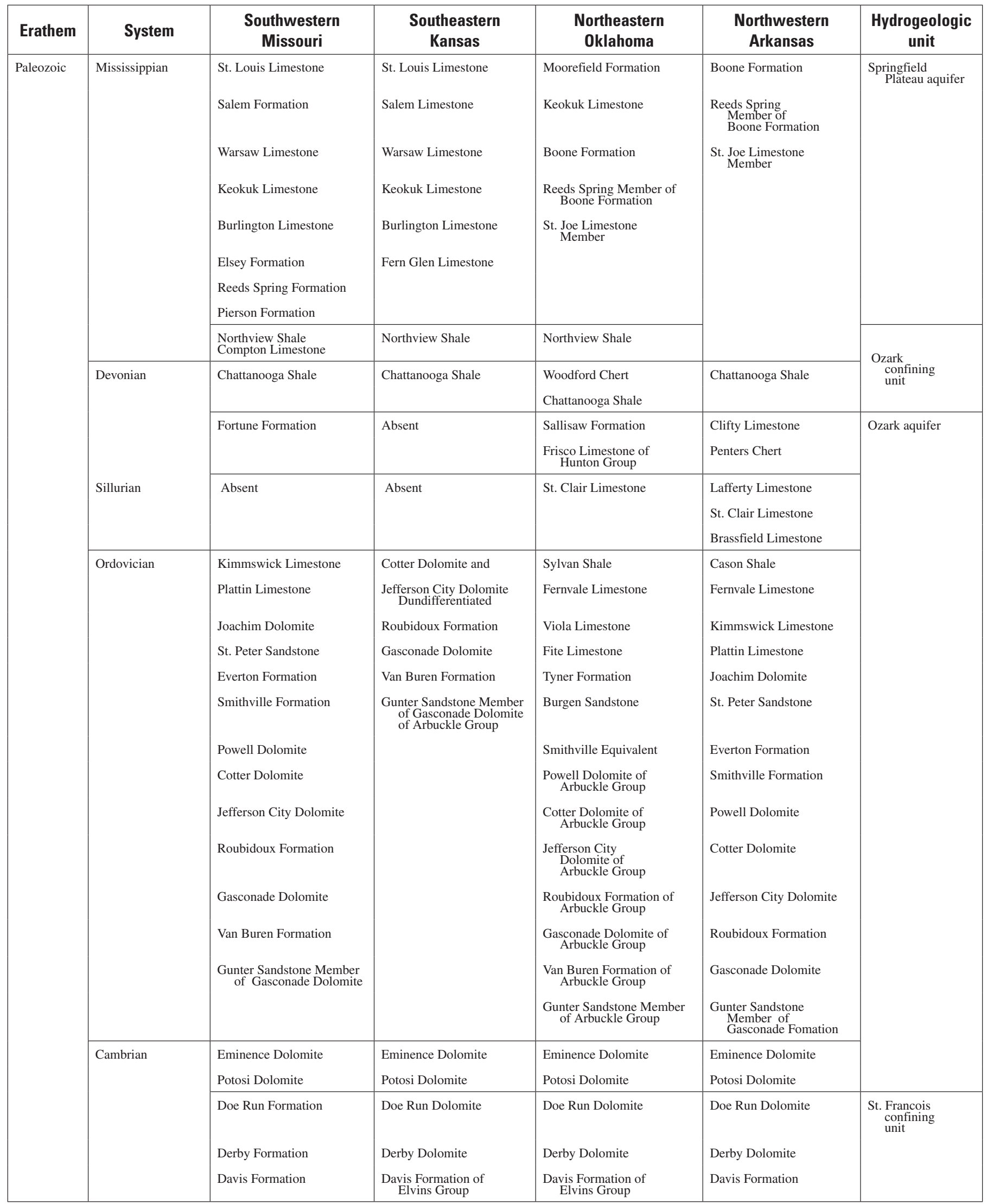


fined over the majority of the study area. In the northwestern part of the study area, the Springfield Plateau aquifer is buried and may be confined. In the majority of the study area, where the Springfield Plateau aquifer crops out, the potentiometric surface represents the water table in the aquifer.

\section{Ozark Aquifer}

The Ozark aquifer consists of Late Cambrian to Middle Devonian water-bearing rocks consisting of dolostone, limestone, and sandstone. The basal formation in the aquifer is the Potosi Dolomite of Cambrian age. The aquifer is overlain by the Ozark confining unit and underlain by the St. Francois confining unit. East of the study area, the Ozark aquifer outcrops at land surface in topographically high areas where direct recharge to the aquifer from infiltration of surface-water runoff and streamflow can occur. Younger formations within the aquifer may not be present as a result of erosion. The Ozark aquifer outcrop coincides with the Springfield-Salem plateaus physiographic section (Fenneman and Johnson, 1946) and within the study area, minor outcrops of the Ozark aquifer exist (fig. 1).

In the western part of the Ozark Plateaus Province within the study area, the Ozark aquifer dips gently to the west. The Ozark aquifer is less than $500 \mathrm{ft}$ below land surface over most of the Springfield Plateau and reaches depths in excess of 1,000 ft below land surface in Kansas and Oklahoma. In the southern area of the Ozark Plateaus Province, the Ozark aquifer is buried to great depths by younger rocks, achieving a depth in excess of 5,000 ft below land surface beneath the Arkansas Valley (fig. 1).

The Ozark aquifer is the thickest and most productive aquifer in the study area. In southeastern Kansas, southwestern Missouri, and northeastern Oklahoma, the Ozark aquifer ranges in thickness from 800 to $1,500 \mathrm{ft}$ (Imes, 1990b). In isolated areas in Oklahoma, the Ozark aquifer may be thinner as a result of highs in the Precambrian basement rocks. In northern Arkansas, the aquifer thickens to the south and ranges from 1,500 to 2,000 ft in thickness (Imes and Emmett, 1994).

The Ozark aquifer comprises several lithologies, which can cause permeability and porosity to vary greatly. Lithologies that comprise the Ozark aquifer include dolostone, limestone, sandstone, chert, and shale, with dolostone being the dominant rock type. Secondary permeability is well developed in the Ozark aquifer. Dissolution of carbonate rocks along fractures and bedding planes has increased permeability. In some areas, karst is well developed (Imes, 1989; Jorgensen and others. 1996). This is especially true in the eastern part of the study area where the Ozark aquifer crops out or is closer to the surface. The Ozark aquifer includes massive, clean, wellsorted sand bodies that are highly permeable in some areas.

The Ozark aquifer is anisotropic and heterogeneous as evidenced by horizontal hydraulic conductivity values that vary from 0.001 to $86 \mathrm{ft} / \mathrm{d}$ (Adamski and others, 1995; Macfarlane and others, 2005). Wells completed in the aquifer yield may yield as much as 2,000 gal/min (Macfarlane, 2007). Static water levels in wells completed in the Ozark aquifer typically will rise above the top of the Ozark aquifer, except in areas where large cones of depression have formed (Imes and Emmett, 1994). The Ozark aquifer receives recharge from its outcrop area in central and south-central Missouri outside the study area; within the study area, recharge originates from the overlying Ozark confining unit. A ground-water divide occurring near the Missouri-Arkansas State line within the study area is indicative of local recharge to the Ozark aquifer. The Ozark aquifer is confined, except for small areas where the Ozark outcrops in Arkansas, Missouri, and Oklahoma, therefore, the potentiometric surface may be higher than the top of the aquifer.

\section{Potentiometric-Surface Construction Methods}

A potentiometric-surface map indicates the altitude to which water levels will rise in tightly cased wells completed in and open to the aquifer, and provides a means to interpret ground-water flow direction. For this study, potentiometricsurface maps (plates 1 and 2) were prepared for the Springfield Plateau aquifer and Ozark aquifer using ground-water level data collected from 285 wells from late March through June of 2006 and water-levels for selected lakes, rivers, and springs. The potentiometric-surface maps represent groundwater conditions during the spring of 2006. During the spring of 2006, the region received less than average rainfall. Dry conditions prior to the spring of 2006 could have contributed to the observed water levels.

Wells were measured using calibrated steel or electric tapes, a sonic device, or air-pressure gage measurements. The calibrated tapes provide a measurement that is accurate to within $0.01 \mathrm{ft}$ (Garber and Koopman, 1968), whereas the sonic and air-pressure methods can provide an accuracy of tenths of feet (Global Water Instrumentation, Inc., 2007; Lohman, 1953). In the case of the air-pressure method, accurate information of the length of the air line may be lacking. In addition, the condition of the air gage used to make the measurement was not always known. These unknowns may lead to substantial error in measurement on the order of 1 to $10 \mathrm{ft}$. The altitude of land surface for the wells was determined by plotting the well on a topographic map and then estimating the altitude at that location using the contours of the topographic map. Both 1:24,000 topographic maps published by USGS and digital quadrangle maps derived from the 1:24,000 topographic maps were used. The contour intervals on the maps were 10 and $20 \mathrm{ft}$, giving a possible error of 5 to $10 \mathrm{ft}$. An effort was made to measure wells that represent the static water level. However, many of the wells measured are in use and are pumped with varying frequency. If a measurement could not be made when the well was not pumping, it was not used. It is possible that some wells had not fully recovered from being 
pumped at the time of measurement, introducing further error. Because of the numerous potential sources for error, suspect data were discarded if it could not be verified.

Points along rivers and lakes were used to approximate water levels within the Springfield Plateau aquifer where it comes in contact with major surface-water bodies. Altitudes of some springs were used as water-level altitude points because they are indicative of a minimum altitude of ground water at the location of the spring. All spring data points were derived from the USGS National Water Information System (NWIS) (http://waterdata.usgs.gov/nwis). Most of the altitude data for springs was derived from topographic maps, giving a possible error of 5-10 ft. Data points representing major streams were obtained from the USGS National Hydrography Dataset (NHD), which are derived from digital topographic maps. In areas where the Springfield Plateau aquifer crops out, every hundredth point representing the altitude of major stream and river surfaces was extracted for use in constructing the potentiometric surface. Horizontal coordinate errors in NHD data can cause substantial error, so the NHD data points were culled to accurately represent the streams. Two major lakes (Grand Lake of the Cherokees and Beaver Lake) occur in the area where the Springfield Plateau aquifer crops out and are considered to be in hydrologic connection with the aquifer. An altitude of $740 \mathrm{ft}$ (NGVD of 1929) (USGS) was used for the Grand Lake of the Cherokees in Oklahoma and an altitude of 1,106 ft (NGVD of 1929) (U.S. Army Corps of Engineers, 2007) was used for Beaver Lake in Arkansas. These altitudes reflect the approximate level of the lakes at the beginning of April 2006.

In the Ozark Plateau region, many wells are completed using surface casing that terminates at the top of the Springfield Plateau aquifer followed by an open borehole to total well depth. This completion technique allows water from both the Springfield Plateau aquifer and the Ozark aquifer to flow into the well. If a well was completed in this manner, a determination was made as to which aquifer the water level represented by comparing the water-level altitude from the well in question with the water-level altitudes of the nearest well pairs completed only in the Springfield Plateau aquifer and the Ozark aquifer. If the water-level altitude in question was within 25 percent of the difference between the waterlevel altitudes from the Springfield Plateau and Ozark aquifer well pair, then it was assigned to the aquifer that was closest to the two. For example, if the water-level altitude in question was $1,275 \mathrm{ft}$, with the nearest Springfield Plateau water-level altitude being $1,300 \mathrm{ft}$ and the nearest Ozark aquifer waterlevel altitude being $1,120 \mathrm{ft}, 25$ percent of the difference $(0.25$ $\mathrm{x}(1,300 \mathrm{ft}-1,120 \mathrm{ft})=45 \mathrm{ft})$ would be used to make the assessment. Because $1,275 \mathrm{ft}$ is only $25 \mathrm{ft}$ different than the Springfield Plateau aquifer water-level altitude, the assignment of that water level would be to the Springfield Plateau aquifer, as opposed to the Ozark aquifer, which is different by $150 \mathrm{ft}$. If no nearby wells had similar characteristics or the waterlevel altitude of the well in question could not be associated with a single aquifer, the water level from the well was not used. Of the 48 water-level altitudes from wells completed in both the Springfield Plateau and Ozark aquifers, 9 were not used. Twenty wells that are completed in the Springfield Plateau and Ozark aquifers were determined to represent the water-level altitude of the Springfield Plateau aquifer. These wells compose 17.5 percent of the wells used to create the potentiometric-surface map of the Springfield Plateau aquifer. Nineteen wells that are completed in the Springfield Plateau and Ozark aquifers were determined to represent the waterlevel altitude of the Ozark aquifer. These wells compose 11.1 percent of the wells used to create the potentiometric-surface map of the Ozark aquifer.

Ground-water levels were measured in 285 wells. Of the 285 wells, 114 wells represented the water-level altitude of the Springfield Plateau aquifer (appendix 1) and 171 wells represented the water-level altitude of the Ozark aquifer (appendix 2). For the Springfield Plateau aquifer, the water-level altitudes at 135 springs (appendix 3) were used, along with 82 points representing major rivers within the study area and 135 points representing the Grand Lake of the Cherokees. For the Ozark aquifer, the water levels at four springs (appendix 4) were used in addition to water levels from the wells.

To create the initial potentiometric surfaces, linear kriging (Gambolati and Volpi, 1979) with a grid size of 6,562 ft was used to create the potentiometric surfaces from the water-level data. Because of the variability of data distribution, a variable search radius was used. After the surface was generated, substantial manual adjustments were made to the contours to honor the data points and to more accurately represent the potentiometric surfaces based on hydrologic judgment.

\section{Potentiometric Surfaces}

A potentiometric-surface map may be used to infer the horizontal direction of ground-water flow. For isotropic conditions, ground water flows perpendicular to the contour lines in a downgradient direction. The potentiometric-surface maps may be used to infer the approximate water-level altitude in the study area, but should not be used to calculate exact depth to ground water in the respective aquifers at specific points because of potential inaccuracies associated with measurement errors (land-surface altitude and depth to water), seasonal variations in water-level altitudes, and errors in interpolating water-level altitudes between sparse data-point locations.

The potentiometric-surface map of the Springfield Plateau aquifer shows a maximum water-level altitude of 1,450 $\mathrm{ft}$ at a spring in Barry County, Missouri (appendix 3), and a minimum water-level altitude of $579 \mathrm{ft}$ at a well in Ottawa County, Oklahoma (plate 1, appendix 1). Ground water in the Springfield Plateau aquifer generally flows to the west in the study area, and to surface-water features (lakes, rivers, and springs) particularly in the southern and eastern parts of the study area where it is closest to land surface. These flow directions generally are similar to the flow directions indicated 
by the predevelopment surface developed by Imes and Emmett (1994, fig. 40). Current (2006) water levels are not the same as the predevelopment surface of Imes and Emmett (1994) because of changing water use over time and differences in potentiometric-surface construction methods.

Minor cones of depression are present in Lawrence and Newton Counties in Missouri and Delaware and Ottawa Counties in Oklahoma. These cones of depression are associated with private wells. The most substantial cone of depression is in Ottawa County, Oklahoma, at a private well near the Grand Lake of the Cherokees. The water level of Grand Lake of the Cherokees is $740 \mathrm{ft}$ and it is believed to be hydrologically connected to the Springfield Plateau aquifer. The water level in the well is $579 \mathrm{ft}$, indicating either high water usage, slow recharge, improper well construction, or poor connection of the lake to the aquifer. In areas where the Springfield Plateau aquifer outcrops, it is the uppermost aquifer over most of the study area and, therefore, the potentiometric surface of the Springfield Plateau aquifer is highly related to the land-surface altitude. This characteristic of the potentiometric surface of the Springfield Plateau aquifer is especially apparent in the southern part of the study area, in particular because of the use of surface-water altitude control points to construct the potentiometric surface. The Springfield Plateau aquifer is also in hydrogeologic connection with many surface-water bodies. In areas where the water level in the Springfield Plateau aquifer is lower than the surface-water body, the body may lose water to the aquifer. If the surface-water body is incised into the aquifer, the aquifer may discharge water to the surface-water body.

Comparison of the potentiometric surface for the Springfield Plateau aquifer (plate 1) with the predevelopment potentiometric surface of Imes and Emmett (1994) shows general agreement, in large part because of the hydrologic controls imparted by streams and springs. However, Beaver Lake in Arkansas and Grand Lake of the Cherokees in Oklahoma are man-made reservoirs that did not exist during predevelopment time, nor did any wells. General flow direction is toward the surface-water drainages represented in each of the maps. Local cones of depression do not appear in plate 1, either because pumping rates are too small, the number of water-level altitude points are too few to show these cones, or the contour interval chosen is too large to represent them.

The potentiometric-surface map of the Ozark aquifer in the study area in 2006 indicates a maximum water level of 1,303 ft at a well in Washington County, Arkansas, and a minimum water level of $390 \mathrm{ft}$ at a well in Ottawa County, Oklahoma (plate 2, appendix 2). The water in the Ozark aquifer generally flows northwestward in the northern part of the study area and westward in the remaining part of the study area.

Substantial cones of depression can be seen on the 2006 potentiometric surface. Cones of depression can be seen in Barry, Barton, Cedar, Dade, Jasper, Lawrence, McDonald, Newton and Vernon Counties in Missouri, Cherokee and Crawford Counties in Kansas, and Craig and Ottawa Coun- ties in Oklahoma. Near the border of Barry and Lawrence Counties, Missouri, there is a cone of depression indicated by a monitoring well. The water-level altitude from a private well nearby also indicates the presence of this cone of depression. In Barton and Vernon Counties, Missouri, and Crawford County, Kansas there are shallow cones of depression indicated by the water-level altitude at rural public water supply wells. In central Jasper County, Missouri, there is a cone of depression indicated by a Missouri Department of Natural Resources monitoring well. In central Newton County, Missouri, there is a cone of depression associated with a public water-supply well field. A cone of depression occurs in the southwestern part McDonald County, Missouri, and includes five public-supply wells and two private wells. A large cone of depression occurs in parts of Craig and Ottawa Counties, Oklahoma. The lowest water level (390 ft) was measured in an observation well near the center of Ottawa County. This cone of depression occurs in an area where several pumping wells withdraw water for public water-supply and industry.

Aside from the cones of depression, the potentiometric surface of the Ozark aquifer generally reflects the changes in altitude of the top of the Ozark aquifer (Imes and Emmett, 1994). A substantial high can be seen in the potentiometric surface of the Ozark aquifer in Benton County, Arkansas. This location coincides with an areally extensive surficial outcrop of the Ozark aquifer, resulting in direct recharge to the aquifer. In addition, small water use in the area may contribute to the high water-level altitude in this area. In other areas, faulting may affect water-level altitudes in the Ozark aquifer. In southcentral McDonald County, Missouri, two nearby wells have water-level altitudes differing by $133 \mathrm{ft}$ and in southwestern Benton County, Arkansas, two nearby wells have water-level altitudes differing by $90 \mathrm{ft}$. These locations are near the Bella Vista fault. It is possible that secondary faulting or jointing influences the ground-water flow in these areas.

A comparison of the 2006 Ozark aquifer potentiometric surface (plate 2) with the predevelopment surface of Imes and Emmett (1994) shows general agreement between the two, except in those areas where cones of depression are depicted in the 2006 map that were not present in predevelopment times. A difference also is apparent in Barry County, Missouri where 2006 potentiometric contours are as much as 200 ft lower than those depicted for predevelopment in the 1994 map.

A comparison of the 2006 Ozark aquifer potentiometricsurface map (plate 2) to the generalized Ozark aquifer potentiometric surface map of Macfarlane and Hathaway (1987), indicates that water levels in 2006 are lower than those depicted in the 1987 map. Both maps depict cones of depression in Crawford County, Kansas, Ottawa County, Oklahoma, and Barton and Jasper Counties in Missouri. However, cones depicted in the 2006 map generally are different in extent and, in one case in Jasper County, Missouri, substantially deeper than those depicted in the 1987 map. It should be noted that differences in contour shapes and altitude between the 2006 and 1987 potentiometric-surface maps could be because of 
water-use induced changes in water levels or because of differences in available data points and the contour intervals used.

On the Macfarlane and Hathaway (1987) potentiometricsurface map, contours in Crawford County, Kansas, depict a southwest-northeast oriented ground-water divide. Because of sparse data points and the 50-ft interval used, potentiometric contours on the 2006 (plate 2) contour map do not depict the presence of this ground-water divide. Again, because of sparse data points in 2006, northwesterly ground-water flow from Crawford County to Neosho County implied from contours on the 1987 map is not depicted by contours on the 2006 contour map (plate 2).

\section{Summary}

The Springfield Plateau and Ozark aquifers are important sources of ground water in the Ozark Plateaus aquifer system. Water from these aquifers is used as municipal, agricultural, industrial, and domestic water sources. Water-use changes and future water-availability questions in these aquifers raises a need for updated potentiometric-surface maps. The U.S. Geological Survey, in cooperation with the Kansas Water Office, conducted a study of the potentiometric surfaces of the Springfield Plateau and Ozark aquifers.

The Springfield Plateau aquifer consists of water-bearing Mississippian-aged limestones and cherts. The Ozark aquifer consists of Late Cambrian to Middle Devonian water-bearing dolostones, limestones, and sandstones. Both aquifers are complex with areally varying lithologies, discrete hydrologic units, varying permeabilities, and secondary permeabilities because of fractures and karst features. The Springfield Plateau aquifer crops out over much of the Springfield Plateau physiographic section and receives recharge from its outcrop area. The Ozark aquifer receives recharge primarily from its outcrop area in central and south-central Missouri.

During the spring of 2006, ground-water levels were measured in 285 wells. Water-level data from these wells, 135 springs, 82 points representing major rivers, and 135 points representing the Grand Lake of the Cherokees were used to create potentiometric-surface maps for the Springfield Plateau and Ozark aquifers using a linear kriging method in conjunction with manual adjustments based on hydrologic judgment. The potentiometric-surface maps represent ground-water conditions during the spring of 2006. During the spring of 2006, the region received less than average rainfall and dry conditions prior to the spring of 2006 could have contributed to the observed water levels.

The potentiometric-surface map of the Springfield Plateau aquifer shows a maximum measured water-level of altitude of about 1,450 ft at a spring in Barry County, Missouri, and a minimum water-level altitude of 579 feet at a well in Ottawa County, Oklahoma. Ground water in the Springfield Plateau aquifer generally flows toward the west in the study area, and to surface-water features (lakes, rivers, and springs) particularly in the southern and eastern parts of the study area where it is closest to land surface. Cones of depression can be seen in Lawrence and Newton Counties in Missouri and Delaware and Ottawa Counties in Oklahoma. These cones of depression are associated with pumping from private wells.

The potentiometric-surface map of the Ozark aquifer in the study area in 2006 indicates a maximum water-level altitude of 1,303 ft in Washington County, Arkansas, and a minimum water-level altitude of $390 \mathrm{ft}$ in Ottawa County, Oklahoma. The water in the Ozark aquifer generally flows northwestward in the northern part of the study area and westward in the remaining study area. Cones of depression occur in Barry, Barton, Cedar, Dade, Jasper, Lawrence, McDonald, Newton, and Vernon Counties in Missouri, Cherokee and Crawford Counties in Kansas, and Craig and Ottawa Counties in Oklahoma. These cones of depression are mainly associated with pumping from public water-supply wells. The flow directions of potentiometric-surface maps of the Springfield Plateau and Ozark aquifers generally agree with the potentiometric-surface maps from previous reports. Differences in water-level altitude, local flow directions, and geometry of the surfaces can be explained by changing water use or differences in available data points and the contour intervals used.

\section{Selected References}

Adamski, J.C., Petersen, J.C., Freiwald, D.A., and Davis, J.V., 1995, Environmental and hydrologic setting of the Ozark Plateaus study unit, Arkansas, Kansas, Missouri,

and Oklahoma: U.S. Geological Survey Water-Resources Investigation Report 94-4022, 69 p.

Fenneman, N.M., and Johnson, D.W., 1946, Physical divisions of the United States (Map): Washington, D.C., U.S. Geological Survey.

Frick, D.R., 1980, Hydrogeology of Mississippian and Ordovician aquifers in southwest Missouri and southeast Kansas: Columbia, University of Missouri, M.S. Thesis, 96 p.

Garber, M.S., and Koopman, F.C., 1968, Methods of measuring water levels in deep wells: U.S. Geological Survey Techniques of Water-Resources Investigations, book 8, chap. A-1, 23 p.

Gambolati, G. and Volpi, G., 1979, A conceptual deterministic analysis of the kriging technique in hydrology: Water Resources Research, v. 15, no. 3, p. 625-629.

Global Water Instrumentation, Inc., 2007, Sonic water level measurement specifications, accessed on August 14, 2007 at URL http://www.globalw.com/products/wl600.html. 
Holland, T.W., 1987, Use of water in Arkansas, 1985: Arkansas Geological Commission Water Resources Summary 16, $27 \mathrm{p}$.

Holland, T.W., 1993, Use of water in Arkansas, 1990: U.S. Geological Survey Open-File Report 93-43, 1 sheet.

Holland, T.W., 1999, Water use in Arkansas, 1995: U.S. Geological Survey Open-File Report 99-188, 1 sheet.

Holland, T.W., 2004, Estimated water use in Arkansas, 2000: U.S. Geological Survey Scientific Investigations Report 2004-5230, 31 p.

Imes, J.L., 1989, Analysis of the effect of pumping on groundwater flow in the Springfield Plateau and Ozark aquifers near Springfield, Missouri: U.S. Geological Survey WaterResources Investigations Report 89-4079, 63 p.

Imes, J.L., 1990a, Major geohydrologic units in and adjacent to the Ozark Plateaus Province, Missouri, Arkansas, Kansas, and Oklahoma: U.S. Geological Survey Hydrologic Investigations Atlas HA-711-A, 1 sheet.

Imes, J.L., 1990b, Major geohydrologic units in and adjacent to the Ozark Plateaus Province, Missouri, Arkansas, Kansas, and Oklahoma-Ozark aquifer: U.S. Geological Survey Hydrologic Investigations Atlas HA-711-E, 3 sheets.

Imes, J.L., and Emmet, L.F., 1994, Geohydrology of the Ozark Plateaus aquifer system in parts of Missouri, Arkansas, Oklahoma, and Kansas: U.S. Geological Survey Professional Paper 1414-D, 127 p.

Jorgensen, D.G., Helgesen, J.O., Signor, D.C., Leonard, R.B., Imes, J.L., Christenson, S.C.,1996, Analysis of regional aquifers in the central Midwest of the United States In Kansas, Nebraska, and parts of Arkansas, Colorado, Missouri, New Mexico, Oklahoma, South Dakota, Texas, and Wyoming: U.S. Geological Survey Professional Paper 1414-A, $67 \mathrm{p}$.

Lohman, S.W., 1953, Measurement of ground-water levels by airline method: U.S. Geological Survey Open-File Report 53-159, 5 p.

Macfarlane, P.A., and Hathaway, L.R., 1987, The hydrogeology and chemical quality of ground waters from the lower Paleozoic aquifers in the Tri-State region of Kansas, Missouri, and Oklahoma: Kansas Geological Survey GroundWater Series 9, 37 p.

Macfarlane, P.A., Healey, J.M., and Wilson, B.B., 2005, The southeast Kansas Ozark aquifer water supply program phase 1 project results: Kansas Geological Survey Open-File Report 2005-15, 52 p.

Macfarlane, P.A., 2007, The southeast Kansas Ozark aquifer water supply program phase 2 project results: Kansas Geological Survey Open-File Report 2007-20, 117 p.
Schrader, T.P., 2005, Potentiometric surface of the Ozark aquifer in northern Arkansas, 2004: U.S. Geological Survey Scientific Investigations Report 2005-5208, 10 p.

U.S. Army Corps of Engineers, 2007, Beaver Monthly Reservoir Report April 2006, accessed on August 17, 2007 at URL http://www.swl-wc.usace.army.mil/WCDS/ mcharts/0604bea.htm. 
Appendixes 1-4 

Appendix 1. Information pertaining to wells completed in the Springfield Plateau aquifer.

[Horizontal datum is North American Datum of 1983 (NAD 83); Vertical datum is National Geodetic Vertical Datum of 1929 (NGVD 29); NA, not available; *, well completed in the Springfield Plateau and Ozark aquifers]

\begin{tabular}{|c|c|c|c|c|c|c|c|}
\hline $\begin{array}{l}\text { Latitude } \\
\text { (decimal } \\
\text { degrees) }\end{array}$ & $\begin{array}{c}\text { Longitude } \\
\text { (decimal } \\
\text { degrees) }\end{array}$ & Station name & $\begin{array}{c}\text { Land-surface } \\
\text { altitude } \\
\text { (feet above } \\
\text { NGVD of 1929) }\end{array}$ & $\begin{array}{c}\text { Well depth } \\
\text { (feet below } \\
\text { land surface) }\end{array}$ & $\begin{array}{c}\text { Depth to } \\
\text { water } \\
\text { (feet below } \\
\text { land surface) }\end{array}$ & $\begin{array}{l}\text { Water-level } \\
\text { altitude } \\
\text { (feet above } \\
\text { NGVD of } \\
\text { 1929) }\end{array}$ & $\begin{array}{c}\text { Date of } \\
\text { measurement }\end{array}$ \\
\hline \multicolumn{8}{|c|}{ Benton County, Arkansas } \\
\hline 36.321 & 94.486 & 19N33W15CDB1 & 1,263 & 153 & 84.57 & $1,178.43$ & $3 / 30 / 2006$ \\
\hline 36.401 & 94.600 & 20N34W21ADC1 & 1,029 & 105 & 12.19 & $1,016.81$ & $3 / 30 / 2006$ \\
\hline 36.288 & 93.911 & 19N28W25ACB1 & 1,450 & 186 & 151.74 & $1,298.26$ & $4 / 03 / 2006$ \\
\hline 36.419 & 93.945 & 20N28W10BDD1 & 1,450 & 25 & 3.44 & $1,446.56$ & $4 / 04 / 2006$ \\
\hline 36.482 & 94.138 & 21N30W23ACB1 & 1,282 & NA & 117.50 & $1,164.50$ & $4 / 04 / 2006$ \\
\hline 36.293 & 94.242 & 19N31W26ADD1 & 1,265 & 120 & 106.95 & $1,158.05$ & $4 / 11 / 2006$ \\
\hline \multicolumn{8}{|c|}{ Washington County, Arkansas } \\
\hline 36.092 & 94.372 & 16N32W03CB1 & 1,163 & 94 & 29.28 & $1,133.72$ & $3 / 10 / 2006$ \\
\hline 35.982 & 94.121 & 15N30W12CCD1 & 1,535 & 412 & 161.80 & $1,373.20$ & $3 / 28 / 2006$ \\
\hline 35.965 & 94.496 & 15N33W21CAC1 & 1,182 & 100 & 29.29 & $1,152.71$ & $3 / 30 / 2006$ \\
\hline 36.170 & 94.201 & 17N30W05DCC1 & 1,322 & NA & 54.95 & $1,267.05$ & $4 / 10 / 2006$ \\
\hline \multicolumn{8}{|c|}{ Cherokee County, Kansas } \\
\hline 37.017 & 94.696 & 35S25E05CDDD & 886 & 220 & 81.90 & 804.10 & $3 / 09 / 2006$ \\
\hline 37.010 & 94.673 & 35S25E09ACDD & 928 & 208 & 91.60 & 836.40 & $3 / 07 / 2006$ \\
\hline 37.052 & 94.704 & 34S25E29CBBB & 818 & 220 & 30.00 & 788.00 & $3 / 09 / 2006$ \\
\hline 37.001 & 94.630 & 35S25E13BBBB & 1,001 & NA & 59.40 & 941.60 & $3 / 09 / 2006$ \\
\hline 37.015 & 94.655 & 35S25E10ABCD & 971 & 263 & 56.30 & 914.70 & $3 / 17 / 2006$ \\
\hline 37.123 & 94.836 & 33S23E36DCAA & 918 & 450 & 88.50 & 829.50 & $3 / 08 / 2006$ \\
\hline 37.148 & 94.785 & 33S24E28ABBA & 869 & 382 & 150.90 & 718.10 & $3 / 11 / 2006$ \\
\hline 37.073 & 94.999 & 34S22E21AACC & 812 & 507 & 127.90 & 684.10 & $3 / 07 / 2006$ \\
\hline 37.141 & 94.793 & 33S24E28CBAB* & 883 & 580 & 181.80 & 701.20 & $3 / 11 / 2006$ \\
\hline 37.043 & 94.653 & 34S25E34AACC* & 850 & 330 & 61.00 & 789.00 & $3 / 07 / 2006$ \\
\hline 37.237 & 94.719 & 32S25E19CCDD* & 897 & 507 & 168.00 & 729.00 & $3 / 10 / 2006$ \\
\hline 37.207 & 94.986 & $33 \mathrm{~S} 22 \mathrm{E} 03 \mathrm{ABBC}^{*}$ & 870 & 807 & 184.40 & 685.60 & $3 / 11 / 2006$ \\
\hline \multicolumn{8}{|c|}{ Crawford County, Kansas } \\
\hline 37.409 & 94.883 & 30S23E27BBDD & 912 & 682 & 227.60 & 684.40 & $3 / 17 / 2006$ \\
\hline 37.403 & 94.669 & 30S25E28DAA2 & 903 & NA & 251.05 & 652.05 & $3 / 29 / 2006$ \\
\hline \multicolumn{8}{|c|}{ Labette County, Kansas } \\
\hline 37.176 & 95.124 & 33S21E17AACD & 914 & 689 & 243.00 & 671.00 & $3 / 07 / 2006$ \\
\hline 37.181 & 95.112 & 33S21E09DCCB & 880 & 675 & 200.60 & 679.40 & $3 / 17 / 2006$ \\
\hline \multicolumn{8}{|c|}{ Barry County, Missouri } \\
\hline 36.564 & 94.013 & 21N29W01DAD & 1,330 & 120 & 31.95 & $1,298.10$ & $3 / 08 / 2006$ \\
\hline 36.702 & 93.980 & 23N28W17CDD & 1,475 & 200 & 76.70 & $1,398.30$ & $3 / 08 / 2006$ \\
\hline 36.765 & 93.942 & 24N28W27ABB & 1,510 & 110 & 85.40 & $1,424.60$ & $3 / 08 / 2006$ \\
\hline 36.650 & 93.902 & 22N28W01ADD & 1,422 & 210 & 70.60 & $1,351.40$ & $3 / 09 / 2006$ \\
\hline
\end{tabular}


Appendix 1. Information pertaining to wells completed in the Springfield Plateau aquifer-Continued

[Horizontal datum is North American Datum of 1983 (NAD 83); Vertical datum is National Geodetic Vertical Datum of 1929 (NGVD 29); NA, not available; *, well completed in the Springfield Plateau and Ozark aquifers]

\begin{tabular}{|c|c|c|c|c|c|c|c|}
\hline $\begin{array}{l}\text { Latitude } \\
\text { (decimal } \\
\text { degrees) }\end{array}$ & $\begin{array}{l}\text { Longitude } \\
\text { (decimal } \\
\text { degrees) }\end{array}$ & Station name & $\begin{array}{c}\text { Land-surface } \\
\text { altitude } \\
\text { (feet above } \\
\text { NGVD of 1929) }\end{array}$ & $\begin{array}{l}\text { Well depth } \\
\text { (feet below } \\
\text { land surface) }\end{array}$ & $\begin{array}{c}\text { Depth to } \\
\text { water } \\
\text { (feet below } \\
\text { land surface) }\end{array}$ & $\begin{array}{l}\text { Water-level } \\
\text { altitude } \\
\text { (feet above } \\
\text { NGVD of } \\
\text { 1929) }\end{array}$ & $\begin{array}{c}\text { Date of } \\
\text { measurement }\end{array}$ \\
\hline \multicolumn{8}{|c|}{ Barry County, Missouri-Continued } \\
\hline 36.771 & 94.050 & 24N29W27AD & 1,395 & 232 & 125.00 & $1,270.00$ & $3 / 09 / 2006$ \\
\hline 36.836 & 93.964 & $25 \mathrm{~N} 28 \mathrm{~W} 35 \mathrm{DB}$ & 1,349 & 210 & 41.60 & $1,307.40$ & $3 / 10 / 2006$ \\
\hline 36.917 & 93.814 & 25N26W31DAC & 1,452 & 332 & 134.70 & $1,317.30$ & $3 / 08 / 2006$ \\
\hline 36.928 & 93.890 & $26 \mathrm{~N} 27 \mathrm{~W} 33 \mathrm{ABB} *$ & 1,372 & 525 & 95.80 & $1,276.20$ & $3 / 08 / 2006$ \\
\hline 36.895 & 93.950 & $25 \mathrm{~N} 28 \mathrm{~W} 12 \mathrm{BDB} *$ & 1,364 & 398 & 213.80 & $1,150.20$ & $3 / 08 / 2006$ \\
\hline \multicolumn{8}{|c|}{ Barton County, Missouri } \\
\hline 37.396 & 94.258 & 31N30W32BAB & 995 & 250 & 131.40 & 863.60 & $3 / 15 / 2006$ \\
\hline \multicolumn{8}{|c|}{ Cedar County, Missouri } \\
\hline 37.827 & 94.014 & 35N28W03CCC & 920 & NA & 85.20 & 834.80 & $3 / 17 / 2006$ \\
\hline \multicolumn{8}{|c|}{ Dade County, Missouri } \\
\hline 37.358 & 93.749 & 30N26W01CCD & 1,060 & 285 & 124.04 & 935.96 & $3 / 16 / 2006$ \\
\hline 37.556 & 93.862 & 33N27W35ACD & 1,028 & 230 & 174.30 & 853.70 & $3 / 16 / 2006$ \\
\hline 37.367 & 93.990 & 30N28W02CBB & 1,125 & NA & 23.10 & $1,101.90$ & $3 / 17 / 2006$ \\
\hline 37.435 & 94.036 & 31N28W08CDC & 1,093 & 425 & 135.80 & 957.20 & $3 / 17 / 2006$ \\
\hline 37.312 & 93.735 & 30N25W30BBB & 1,157 & 190 & 40.48 & $1,116.52$ & $3 / 15 / 2006$ \\
\hline 37.315 & 93.736 & 30N26W24DDD & 1,070 & 150 & 14.82 & $1,055.18$ & $3 / 15 / 2006$ \\
\hline \multicolumn{8}{|c|}{ Geene County, Missouri } \\
\hline 37.237 & 93.421 & NA & 1,254 & 170 & 69.00 & $1,185.00$ & $6 / 16 / 2006$ \\
\hline 37.253 & 93.415 & NA & 1,230 & 71 & 16.40 & $1,213.60$ & $6 / 14 / 2006$ \\
\hline 37.411 & 93.521 & NA & 1,175 & NA & 43.60 & $1,131.40$ & $6 / 20 / 2006$ \\
\hline \multicolumn{8}{|c|}{ Jasper County, Missouri } \\
\hline 37.076 & 94.381 & $27 \mathrm{~N} 32 \mathrm{~W} 12 \mathrm{~A}$ & 1,052 & 145 & 76.60 & 975.40 & $3 / 09 / 2006$ \\
\hline 37.072 & 94.447 & 27N32W08DCA & 1,080 & 359 & 97.10 & 982.90 & $3 / 09 / 2006$ \\
\hline 37.187 & 94.359 & 29N31W31CDA & 972 & 195 & 55.40 & 916.60 & $3 / 09 / 2006$ \\
\hline 37.144 & 94.421 & 28N32W16DDA & 985 & 220 & 36.80 & 948.20 & $3 / 10 / 2006$ \\
\hline 37.160 & 94.393 & 28N32W11DBB & 940 & 180 & 51.60 & 888.40 & $3 / 10 / 2006$ \\
\hline 37.185 & 94.545 & 28N33W05AAA & 902 & 265 & 47.65 & 854.35 & $3 / 09 / 2006$ \\
\hline 37.196 & 94.130 & 29N29W30DDC & 1,120 & 220 & 69.60 & $1,050.40$ & $3 / 09 / 2006$ \\
\hline 37.262 & 94.395 & 29N32W02CCA* & 950 & 263 & 64.30 & 885.70 & $3 / 10 / 2006$ \\
\hline 37.262 & 94.395 & 29N32W02C & 945 & NA & 46.70 & 898.30 & $3 / 10 / 2006$ \\
\hline 37.205 & 94.225 & 29N30W29DBB & 1,038 & 200 & 90.60 & 947.40 & $3 / 16 / 2006$ \\
\hline 37.075 & 94.437 & 27N32W09CBA & 1,035 & 160 & 19.20 & $1,015.80$ & $3 / 16 / 2006$ \\
\hline 37.074 & 94.447 & 27N32W08DBD & 1,085 & 400 & 93.70 & 991.30 & $3 / 16 / 2006$ \\
\hline 37.339 & 94.289 & 30N31W24ABA & 968 & NA & 16.61 & 951.39 & $3 / 14 / 2006$ \\
\hline 37.341 & 94.328 & 30N31W15DCD & 925 & 160 & 25.10 & 899.90 & $3 / 14 / 2006$ \\
\hline
\end{tabular}


Appendix 1. Information pertaining to wells completed in the Springfield Plateau aquifer-Continued

[Horizontal datum is North American Datum of 1983 (NAD 83); Vertical datum is National Geodetic Vertical Datum of 1929 (NGVD 29); NA, not available; *, well completed in the Springfield Plateau and Ozark aquifers]

\begin{tabular}{|c|c|c|c|c|c|c|c|}
\hline $\begin{array}{l}\text { Latitude } \\
\text { (decimal } \\
\text { degrees) }\end{array}$ & $\begin{array}{l}\text { Longitude } \\
\text { (decimal } \\
\text { degrees) }\end{array}$ & Station name & $\begin{array}{c}\text { Land-surface } \\
\text { altitude } \\
\text { (feet above } \\
\text { NGVD of 1929) }\end{array}$ & $\begin{array}{l}\text { Well depth } \\
\text { (feet below } \\
\text { land surface) }\end{array}$ & 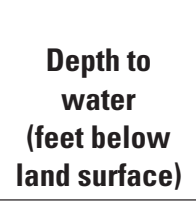 & $\begin{array}{l}\text { Water-level } \\
\text { altitude } \\
\text { (feet above } \\
\text { NGVD of } \\
\text { 1929) }\end{array}$ & $\begin{array}{c}\text { Date of } \\
\text { measurement }\end{array}$ \\
\hline \multicolumn{8}{|c|}{ Jasper County, Missouri-Continued } \\
\hline 37.162 & 94.393 & 28N32W11CAA & 950 & 405 & 74.30 & 875.70 & $3 / 10 / 2006$ \\
\hline 37.239 & 94.422 & 29N32W09DDC* & 980 & 605 & 119.20 & 860.80 & $3 / 10 / 2006$ \\
\hline 37.204 & 94.223 & 29N30W29DBA* & 1,045 & 450 & 91.60 & 953.40 & $3 / 16 / 2006$ \\
\hline \multicolumn{8}{|c|}{ Lawrence County, Missouri } \\
\hline 36.932 & 93.809 & 26N26W28CBB & 1,375 & 75 & 62.60 & $1,312.40$ & $3 / 14 / 2006$ \\
\hline 37.017 & 93.907 & 27N27W29CDD & 1,338 & 189 & 68.00 & $1,270.00$ & $3 / 14 / 2006$ \\
\hline 37.075 & 94.016 & $27 \mathrm{~N} 28 \mathrm{~W} 08 \mathrm{BAB} *$ & 1,245 & 511 & 166.10 & $1,078.90$ & $3 / 14 / 2006$ \\
\hline 37.164 & 94.013 & 28N28W05CDD* & 1,150 & 450 & 101.50 & $1,048.50$ & $3 / 14 / 2006$ \\
\hline 37.010 & 93.899 & 27N27W32ADD* & 1,330 & 600 & 113.90 & $1,216.10$ & $3 / 14 / 2006$ \\
\hline 37.246 & 93.949 & 29N28W11AAC* & 1,210 & 330 & 119.00 & $1,091.00$ & $3 / 15 / 2006$ \\
\hline 36.943 & 93.711 & NA & 1,517 & 704 & 134.90 & $1,382.10$ & $6 / 20 / 2006$ \\
\hline 37.025 & 93.631 & NA & 1,340 & 549 & 58.30 & $1,281.70$ & $6 / 20 / 2006$ \\
\hline 37.071 & 93.713 & NA & 1,336 & 300 & 168.30 & $1,167.70$ & $6 / 20 / 2006$ \\
\hline 37.104 & 93.635 & NA & 1,247 & 500 & 98.50 & $1,148.50$ & $6 / 20 / 2006$ \\
\hline 36.944 & 93.770 & NA & 1,375 & 200 & 67.50 & $1,307.50$ & $3 / 16 / 2006$ \\
\hline \multicolumn{8}{|c|}{ McDonald County, Missouri } \\
\hline 36.723 & 94.204 & 23N30W18AAA* & 1,309 & 200 & 52.80 & $1,256.20$ & $3 / 06 / 2006$ \\
\hline 36.742 & 94.088 & 23N29W05BDD & 1,340 & 160 & 74.05 & $1,265.95$ & $3 / 06 / 2006$ \\
\hline 36.720 & 94.203 & 23N30W18AAA & 1,299 & 346 & 162.98 & $1,136.02$ & $3 / 07 / 2006$ \\
\hline 36.745 & 94.417 & 23N32W06DDD* & 1,247 & NA & 117.90 & $1,129.10$ & $3 / 06 / 2006$ \\
\hline 36.723 & 94.206 & 23N30W18AAA & 1,309 & 660 & 183.30 & $1,125.70$ & $3 / 06 / 2006$ \\
\hline \multicolumn{8}{|c|}{ Newton County, Missouri } \\
\hline 36.868 & 94.445 & $25 \mathrm{~N} 32 \mathrm{~W} 21 \mathrm{CCB}$ & 1,140 & 220 & 112.50 & $1,027.50$ & $3 / 06 / 2006$ \\
\hline 36.992 & 94.532 & $26 \mathrm{~N} 33 \mathrm{~W} 10 \mathrm{BCB}$ & 1,110 & 120 & 76.50 & $1,033.50$ & $3 / 07 / 2006$ \\
\hline 36.993 & 94.533 & 26N33W10BCB & 1,110 & 130 & 83.20 & $1,026.80$ & 3/07/2006 \\
\hline 37.016 & 94.582 & 27N33W31CAC* & 1,040 & 304 & 152.20 & 887.80 & 3/07/2006 \\
\hline 37.008 & 94.297 & 27N31W03AAA & 1,185 & 165 & 58.90 & $1,126.10$ & $3 / 08 / 2006$ \\
\hline 36.758 & 94.166 & 24N30W33DAA & 1,252 & 100 & 75.20 & $1,176.80$ & $3 / 08 / 2006$ \\
\hline 36.905 & 94.481 & $25 \mathrm{~N} 32 \mathrm{~W} 07 \mathrm{BCB}$ & 1,115 & 200 & 102.10 & $1,012.90$ & $3 / 08 / 2006$ \\
\hline 36.752 & 94.087 & $24 \mathrm{~N} 29 \mathrm{~W} 32 \mathrm{CAD}$ & 1,315 & 200 & 49.60 & $1,265.40$ & $3 / 06 / 2006$ \\
\hline 36.893 & 94.140 & 25N30W07DDB & 1,220 & 230 & 72.60 & $1,147.40$ & $3 / 08 / 2006$ \\
\hline 37.012 & 94.542 & 26N33W04ABB & 1,085 & 180 & 137.20 & 947.80 & $3 / 16 / 2006$ \\
\hline 36.949 & 94.517 & $26 \mathrm{~N} 33 \mathrm{~W} 27 \mathrm{ADA}$ & 1,185 & 250 & 118.20 & $1,066.80$ & $3 / 16 / 2006$ \\
\hline 36.975 & 94.527 & 26N33W15CAA* & 1,110 & 492 & 119.10 & 990.90 & $3 / 08 / 2006$ \\
\hline 36.911 & 94.343 & 25N31W05DCB* & 1,042 & 251 & 55.48 & 986.52 & $3 / 08 / 2006$ \\
\hline
\end{tabular}


Appendix 1. Information pertaining to wells completed in the Springfield Plateau aquifer-_Continued

[Horizontal datum is North American Datum of 1983 (NAD 83); Vertical datum is National Geodetic Vertical Datum of 1929 (NGVD 29); NA, not available; *, well completed in the Springfield Plateau and Ozark aquifers]

\begin{tabular}{|c|c|c|c|c|c|c|c|}
\hline $\begin{array}{l}\text { Latitude } \\
\text { (decimal } \\
\text { degrees) }\end{array}$ & $\begin{array}{c}\text { Longitude } \\
\text { (decimal } \\
\text { degrees) }\end{array}$ & Station name & $\begin{array}{c}\text { Land-surface } \\
\text { altitude } \\
\text { (feet above } \\
\text { NGVD of 1929) }\end{array}$ & $\begin{array}{l}\text { Well depth } \\
\text { (feet below } \\
\text { land surface) }\end{array}$ & $\begin{array}{c}\text { Depth to } \\
\text { water } \\
\text { (feet below } \\
\text { land surface) }\end{array}$ & $\begin{array}{l}\text { Water-level } \\
\text { altitude } \\
\text { (feet above } \\
\text { NGVD of } \\
\text { 1929) }\end{array}$ & $\begin{array}{c}\text { Date of } \\
\text { measurement }\end{array}$ \\
\hline \multicolumn{8}{|c|}{ Newton County, Missouri-Continued } \\
\hline 36.758 & 94.166 & 24N30W33DAA* & 1,252 & 505 & 76.00 & $1,176.00$ & $3 / 08 / 2006$ \\
\hline 37.009 & 94.296 & 27N31W02BBB* & 1,180 & 430 & 110.70 & $1,069.30$ & $3 / 08 / 2006$ \\
\hline \multicolumn{8}{|c|}{ Vernon County, Missouri } \\
\hline 37.934 & 94.235 & 36N30W04ABB & 875 & NA & 16.03 & 858.97 & $3 / 16 / 2006$ \\
\hline \multicolumn{8}{|c|}{ Craig County, Oklahoma } \\
\hline 36.723 & 95.037 & NA & 740 & NA & 127.80 & 612.20 & $3 / 23 / 2006$ \\
\hline 36.906 & 95.033 & NA & 835 & 60.5 & 16.36 & 818.64 & $3 / 29 / 2006$ \\
\hline \multicolumn{8}{|c|}{ Delaware County, Oklahoma } \\
\hline 36.383 & 94.825 & NA & 960 & 200 & 85.35 & 874.65 & $3 / 21 / 2006$ \\
\hline 36.438 & 94.666 & NA & 1,080 & 760 & 321.50 & 758.50 & $3 / 30 / 2006$ \\
\hline 36.591 & 94.665 & NA & 885 & 484 & 81.02 & 803.98 & $3 / 22 / 2006$ \\
\hline 36.202 & 94.921 & NA & 1,120 & 80 & 50.79 & $1,069.21$ & $3 / 24 / 2006$ \\
\hline 36.223 & 94.707 & NA & 1,140 & 170 & 89.67 & $1,050.33$ & $3 / 22 / 2006$ \\
\hline 36.313 & 94.992 & NA & 780 & 400 & 21.59 & 758.41 & $3 / 21 / 2006$ \\
\hline \multicolumn{8}{|c|}{ Ottawa County, Oklahoma } \\
\hline 36.982 & 94.813 & NA & 830 & 828 & 33.05 & 796.95 & $3 / 28 / 2006$ \\
\hline 36.987 & 94.741 & NA & 840 & NA & 17.45 & 822.55 & $3 / 28 / 2006$ \\
\hline 36.960 & 94.858 & NA & 827 & 289 & 33.66 & 793.34 & $3 / 23 / 2006$ \\
\hline 36.995 & 94.845 & NA & 820 & 116 & 35.46 & 784.54 & $3 / 23 / 2006$ \\
\hline 36.937 & 94.913 & NA & 780 & 17.2 & 16.23 & 763.77 & $3 / 29 / 2006$ \\
\hline 36.921 & 94.688 & NA & 929 & 455 & 60.00 & 869.00 & $2 / 28 / 2006$ \\
\hline 36.930 & 94.720 & NA & 860 & 250 & 86.00 & 774.00 & $3 / 28 / 2006$ \\
\hline 36.810 & 94.788 & NA & 810 & 125 & 71.30 & 738.70 & $3 / 23 / 2006$ \\
\hline 36.930 & 94.913 & NA & 780 & 210 & 20.10 & 759.90 & $3 / 29 / 2006$ \\
\hline 36.816 & 94.891 & NA & 805 & 277 & 44.98 & 760.02 & $3 / 29 / 2006$ \\
\hline 36.764 & 94.732 & NA & 900 & 430 & 320.60 & 579.40 & $3 / 29 / 2006$ \\
\hline
\end{tabular}


Appendix 2. Information pertaining to wells completed in the Ozark aquifer.

[Horizontal datum is North American Datum of 1983 (NAD 83); Vertical datum is National Geodetic Vertical Datum of 1929 (NGVD 29); NA, not available; *, well completed in the Springfield and Ozark aquifers]

\begin{tabular}{|c|c|c|c|c|c|c|c|}
\hline $\begin{array}{l}\text { Latitude } \\
\text { (decimal } \\
\text { degrees) }\end{array}$ & $\begin{array}{c}\text { Longitude } \\
\text { (decimal } \\
\text { degrees) }\end{array}$ & Station name & $\begin{array}{c}\text { Land- surface } \\
\text { altitude } \\
\text { (feet above } \\
\text { NGVD of 1929) }\end{array}$ & $\begin{array}{c}\text { Well depth } \\
\text { (feet below } \\
\text { land } \\
\text { surface) }\end{array}$ & $\begin{array}{l}\text { Depth to } \\
\text { water } \\
\text { (feet below } \\
\text { land } \\
\text { surface) }\end{array}$ & $\begin{array}{c}\text { Water-level } \\
\text { altitude } \\
\text { (feet above } \\
\text { NGVD of 1929) }\end{array}$ & $\begin{array}{c}\text { Date of } \\
\text { measurement }\end{array}$ \\
\hline \multicolumn{8}{|c|}{ Benton County, Arkansas } \\
\hline 36.335 & 93.932 & 19N28W11BAD1 & 1,260 & 1,030 & 202.29 & $1,057.71$ & $4 / 04 / 2006$ \\
\hline 36.332 & 94.105 & 19N29W07DAA1 & 1,210 & 1,659 & 139.10 & $1,070.90$ & $4 / 04 / 2006$ \\
\hline 36.175 & 94.425 & 17N32W06DDA1 & 1,061 & 425 & 86.69 & 974.31 & $4 / 05 / 2006$ \\
\hline 36.173 & 94.426 & 17N32W06DDD1 & 1,040 & 700 & 156.13 & 883.87 & $4 / 05 / 2006$ \\
\hline 36.259 & 94.440 & 18N33W01DDD1 & 1,235 & 1,235 & 94.90 & $1,140.10$ & $4 / 05 / 2006$ \\
\hline 36.262 & 94.421 & $18 \mathrm{~N} 32 \mathrm{~W} 05 \mathrm{CBC} 3$ & 1,205 & 150 & 95.15 & $1,109.85$ & $4 / 10 / 2006$ \\
\hline 36.373 & 94.288 & 20N31W28CCA1 & 1,313 & 610 & 82.47 & $1,230.53$ & $4 / 11 / 2006$ \\
\hline \multicolumn{8}{|c|}{ Washington County, Arkansas } \\
\hline 36.086 & 94.378 & 16N32W09ABD1 & 1,135 & 1,815 & 141.48 & 993.52 & $3 / 10 / 2006$ \\
\hline 35.984 & 94.302 & 15N31W17BBD1 & 1,195 & 2,097 & 45.70 & $1,149.30$ & $3 / 28 / 2006$ \\
\hline 36.138 & 94.031 & 17N29W13CCC1 & 1,330 & NA & 26.66 & $1,303.34$ & $4 / 03 / 2006$ \\
\hline 36.131 & 94.234 & 17N31W24DBD1 & 1,140 & 220 & 68.84 & $1,071.16$ & $4 / 17 / 2006$ \\
\hline \multicolumn{8}{|c|}{ Allen County, Kansas } \\
\hline 37.776 & 95.513 & 28S17E23ABBA & 966 & 1,501 & 295.0 & 671.00 & $3 / 03 / 2006$ \\
\hline \multicolumn{8}{|c|}{ Cherokee County, Kansas } \\
\hline 37.093 & 94.704 & 34S25E08CBC1 & 849 & NA & 132.82 & 715.93 & $3 / 21 / 2006$ \\
\hline 37.074 & 94.693 & 34S25E20BAB1 & 825 & NA & 141.35 & 683.90 & $3 / 21 / 2006$ \\
\hline 37.064 & 94.669 & 34S25E21DAB1 & 918 & NA & 161.40 & 756.31 & $3 / 17 / 2006$ \\
\hline 37.060 & 94.677 & 34S25E28BBB2 & 912 & NA & 136.72 & 774.99 & $3 / 21 / 2006$ \\
\hline 37.072 & 94.632 & 34S25E23AAD1 & 961 & NA & 198.85 & 761.90 & $3 / 29 / 2006$ \\
\hline 37.075 & 94.631 & 34S25E13CCC4 & 963 & NA & 281.33 & 681.50 & $3 / 13 / 2006$ \\
\hline 37.089 & 94.639 & 34S25E14ABB3 & 949 & NA & 145.20 & 803.80 & $3 / 13 / 2006$ \\
\hline 37.046 & 94.737 & 34S24E36BBA6 & 822 & NA & 226.45 & 595.85 & $3 / 17 / 2006$ \\
\hline 37.037 & 94.735 & 34S24E36CBB5 & 826 & NA & 140.72 & 685.53 & $3 / 17 / 2006$ \\
\hline 37.075 & 94.804 & 34S24E17DCC1 & 856 & NA & 183.85 & 672.32 & $3 / 21 / 2006$ \\
\hline 37.117 & 94.675 & 34S25E04ABA1 & 853 & NA & 111.45 & 741.55 & $2 / 28 / 2006$ \\
\hline 37.170 & 94.705 & 33S25E18DAA1 & 871 & NA & 162.46 & 708.44 & $3 / 29 / 2006$ \\
\hline 37.180 & 94.669 & 33S25E09DAD2 & 885 & NA & 110.19 & 775.01 & $3 / 29 / 2006$ \\
\hline 37.177 & 94.843 & 32S23E13BAA4 & 894 & NA & 203.78 & 690.35 & $3 / 21 / 2006$ \\
\hline 37.237 & 94.813 & 32S24E29BBB1 & 912 & NA & 238.58 & 673.42 & $3 / 21 / 2006$ \\
\hline 37.313 & 94.771 & 31S24E27CDB1 & 924 & NA & 253.10 & 670.98 & $3 / 21 / 2006$ \\
\hline 37.141 & 94.793 & $33 \mathrm{~S} 24 \mathrm{E} 28 \mathrm{CBAB} *$ & 883 & 580 & 181.80 & 701.20 & $3 / 11 / 2006$ \\
\hline 37.174 & 94.809 & 33S24E17BCAA* & 896 & 757 & 209.20 & 686.80 & $3 / 08 / 2006$ \\
\hline
\end{tabular}


Appendix 2. Information pertaining to wells completed in the Ozark aquifer.-Continued

[Horizontal datum is North American Datum of 1983 (NAD 83); Vertical datum is National Geodetic Vertical Datum of 1929 (NGVD 29); NA, not available; *, well completed in the Springfield and Ozark aquifers]

\begin{tabular}{|c|c|c|c|c|c|c|c|}
\hline $\begin{array}{l}\text { Latitude } \\
\text { (decimal } \\
\text { degrees) }\end{array}$ & $\begin{array}{c}\text { Longitude } \\
\text { (decimal } \\
\text { degrees) }\end{array}$ & Station name & $\begin{array}{l}\text { Land- surface } \\
\text { altitude } \\
\text { (feet above } \\
\text { NGVD of 1929) }\end{array}$ & $\begin{array}{c}\text { Well depth } \\
\text { (feet below } \\
\text { land } \\
\text { surface) }\end{array}$ & $\begin{array}{l}\text { Depth to } \\
\text { water } \\
\text { (feet below } \\
\text { land } \\
\text { surface) }\end{array}$ & $\begin{array}{c}\text { Water-level } \\
\text { altitude } \\
\text { (feet above } \\
\text { NGVD of 1929) }\end{array}$ & $\begin{array}{c}\text { Date of } \\
\text { measurement }\end{array}$ \\
\hline \multicolumn{8}{|c|}{ Crawford County, Kansas } \\
\hline 37.385 & 94.746 & NA & 904 & 1,275 & 237.00 & 666.70 & $3 / 10 / 2006$ \\
\hline 37.464 & 94.779 & 29S25E05CDD1 & 1,021 & NA & 337.02 & 683.48 & $3 / 20 / 2006$ \\
\hline 37.458 & 94.683 & 30S25E04CCA1 & 954 & NA & 291.19 & 663.08 & $3 / 22 / 2006$ \\
\hline 37.398 & 94.670 & 30S24E28DDD11 & 900 & NA & 252.86 & 646.84 & $3 / 29 / 2006$ \\
\hline 37.536 & 94.742 & 30S24E21ADA3 & 922 & NA & 248.38 & 673.62 & $3 / 20 / 2006$ \\
\hline 37.398 & 94.670 & 28S25E01ACA2 & 836 & NA & 156.79 & 679.66 & $3 / 22 / 2006$ \\
\hline 37.457 & 94.742 & 30S24E02DDD & 948 & NA & 273.50 & 674.80 & $3 / 29 / 2006$ \\
\hline 37.403 & 94.669 & 30S25E28DAA1 & 904 & NA & 261.97 & 641.63 & $3 / 29 / 2006$ \\
\hline 37.411 & 94.780 & 30S24E28AAA1 & 928 & NA & 249.75 & 678.55 & $3 / 21 / 2006$ \\
\hline 37.353 & 94.778 & 31S24E16AAA3 & 909 & NA & 239.10 & 670.30 & $3 / 21 / 2006$ \\
\hline 37.461 & 94.645 & 30S25E23CCD1 & 926 & NA & 282.24 & 644.16 & $3 / 29 / 2006$ \\
\hline \multicolumn{8}{|c|}{ Labette County, Kansas } \\
\hline 37.018 & 95.091 & 35S21E03DCDD & 826 & 1,400 & 139.90 & 686.10 & $3 / 07 / 2006$ \\
\hline \multicolumn{8}{|c|}{ Neosho County, Kansas } \\
\hline 37.599 & 95.252 & 28S20E20BBCB & 955 & 1,300 & 268.40 & 686.60 & $3 / 09 / 2006$ \\
\hline \multicolumn{8}{|c|}{ Barry County, Missouri } \\
\hline 36.914 & 93.932 & 25N27W06BAB & 1,287 & 1,475 & 417.20 & 869.80 & $3 / 06 / 2006$ \\
\hline 36.678 & 93.842 & 23N27W27BDC & 1,465 & 1,470 & 422.90 & $1,042.10$ & $3 / 09 / 2006$ \\
\hline 36.680 & 93.869 & 23N27W29A & 1,335 & 1,200 & 383.90 & 951.10 & $3 / 09 / 2006$ \\
\hline 36.670 & 93.933 & 23N28W35BBD & 1,501 & 1,002 & 277.20 & $1,223.80$ & $3 / 09 / 2006$ \\
\hline 36.670 & 93.942 & 23N28W34ABD & 1,555 & 1,022 & 337.00 & $1,218.00$ & $3 / 09 / 2006$ \\
\hline 36.922 & 93.922 & 26N27W31DD & 1,308 & 1,400 & 507.70 & 800.30 & $3 / 06 / 2006$ \\
\hline 36.815 & 93.919 & 24N27W11ACA & 1,467 & 928 & 262.70 & $1,204.30$ & $3 / 07 / 2006$ \\
\hline 36.577 & 93.815 & 22N27W35AD & 1,042 & 100 & 41.90 & $1,000.10$ & $3 / 07 / 2006$ \\
\hline 36.640 & 93.637 & 22N25W4DDB & 1,100 & 380 & 106.20 & 993.80 & $3 / 07 / 2006$ \\
\hline 36.722 & 93.674 & 23N25W07ABC & 1,222 & NA & 163.90 & $1,058.10$ & $3 / 07 / 2006$ \\
\hline 36.825 & 93.650 & 24N25W34DAD & 1,530 & 600 & 297.20 & $1,232.80$ & $6 / 21 / 2006$ \\
\hline 36.677 & 93.891 & NA & 1,460 & 1500 & 370.00 & $1,090.00$ & $3 / 10 / 2006$ \\
\hline \multicolumn{8}{|c|}{ Barton County, Missouri } \\
\hline 37.394 & 94.091 & 31N29W26CDD & 1,060 & 893 & 263.01 & 796.99 & $3 / 14 / 2006$ \\
\hline 37.499 & 94.269 & 32N30W30ABB & 975 & 981 & 296.97 & 678.03 & $3 / 14 / 2006$ \\
\hline 37.502 & 94.307 & 32N31W26BDD & 995 & 1,200 & 328.00 & 665.00 & $3 / 15 / 2006$ \\
\hline 37.531 & 94.352 & 32N31W17AAA & 995 & 900 & 328.00 & 665.00 & $3 / 15 / 2006$ \\
\hline 37.590 & 94.457 & $33 \mathrm{~N} 32 \mathrm{~W} 28 \mathrm{BBB}$ & 970 & 905 & 306.00 & 662.00 & $3 / 15 / 2006$ \\
\hline 37.431 & 94.428 & 31N32W22AAA & 995 & 900 & 361.00 & 632.00 & $3 / 15 / 2006$ \\
\hline
\end{tabular}


Appendix 2. Information pertaining to wells completed in the Ozark aquifer-Continued

[Horizontal datum is North American Datum of 1983 (NAD 83); Vertical datum is National Geodetic Vertical Datum of 1929 (NGVD 29); NA, not available; *, well completed in the Springfield and Ozark aquifers]

\begin{tabular}{|c|c|c|c|c|c|c|c|}
\hline $\begin{array}{l}\text { Latitude } \\
\text { (decimal } \\
\text { degrees) }\end{array}$ & $\begin{array}{l}\text { Longitude } \\
\text { (decimal } \\
\text { degrees) }\end{array}$ & Station name & $\begin{array}{c}\text { Land- surface } \\
\text { altitude } \\
\text { (feet above } \\
\text { NGVD of 1929) }\end{array}$ & $\begin{array}{c}\text { Well depth } \\
\text { (feet below } \\
\text { land } \\
\text { surface) }\end{array}$ & $\begin{array}{c}\text { Depth to } \\
\text { water } \\
\text { (feet below } \\
\text { land } \\
\text { surface) }\end{array}$ & $\begin{array}{c}\text { Water-level } \\
\text { altitude } \\
\text { (feet above } \\
\text { NGVD of 1929) }\end{array}$ & $\begin{array}{c}\text { Date of } \\
\text { measurement }\end{array}$ \\
\hline \multicolumn{8}{|c|}{ Barton County, Missouri-Continued } \\
\hline 37.573 & 94.245 & 33N30W29DCD & 985 & 1,135 & 284.00 & 699.00 & $3 / 15 / 2006$ \\
\hline 37.492 & 94.207 & 32N30W27ADD & 1,030 & 940 & 390.00 & 638.00 & $3 / 15 / 2006$ \\
\hline \multicolumn{8}{|c|}{ Cedar County, Missouri } \\
\hline 37.609 & 94.001 & 33N28W15BBB & 1,065 & 1,215 & 317.00 & 746.00 & $3 / 15 / 2006$ \\
\hline 37.858 & 94.017 & 36N28W28DCA & 950 & 1,007 & 298.00 & 650.00 & $3 / 17 / 2006$ \\
\hline 37.730 & 93.918 & 34N28W05CDC* & 933 & 485 & 228.50 & 704.50 & $3 / 17 / 2006$ \\
\hline 37.580 & 93.973 & 33N28W23DCC* & 952 & 400 & 234.10 & 717.90 & $3 / 15 / 2006$ \\
\hline \multicolumn{8}{|c|}{ Christian County, Missouri } \\
\hline 37.031 & 93.474 & 27N23W20BDD & 1394 & 1,300 & 300.00 & $1,094.00$ & $6 / 15 / 2006$ \\
\hline \multicolumn{8}{|c|}{ Dade County, Missouri } \\
\hline 37.415 & 93.848 & 31N27W24AAC & 1,080 & 1,585 & 139.30 & 938.00 & $3 / 15 / 2006$ \\
\hline 37.479 & 93.852 & $32 \mathrm{~N} 27 \mathrm{~W} 25 \mathrm{CDA}$ & 1,033 & 565 & 249.80 & 783.20 & $3 / 16 / 2006$ \\
\hline 37.513 & 93.808 & 32N26W17ACD & 1,003 & 700 & 273.80 & 729.20 & $3 / 16 / 2006$ \\
\hline 37.341 & 93.704 & 30N25W17ABA & 1,065 & 892 & 101.60 & 963.40 & $3 / 17 / 2006$ \\
\hline 37.293 & 93.883 & 30N27W34DAD* & 1,128 & 245 & 120.40 & $1,007.60$ & $3 / 16 / 2006$ \\
\hline 37.447 & 93.897 & 31N27W09AAA* & 940 & 345 & 168.87 & 771.13 & $3 / 16 / 2006$ \\
\hline 37.326 & 93.720 & 30N25W19AAA* & 1,130 & 450 & 139.80 & 990.20 & $3 / 15 / 2006$ \\
\hline 37.476 & 93.825 & $32 \mathrm{~N} 26 \mathrm{~W} 30 \mathrm{DDC}^{*}$ & 1,000 & 426 & 217.00 & 783.00 & $3 / 17 / 2006$ \\
\hline 37.549 & 93.814 & 33N26W32CCD* & 1,035 & 425 & 313.10 & 721.90 & $3 / 17 / 2006$ \\
\hline 37.349 & 93.696 & 30N25W09CBB & 1,120 & 476 & 296.20 & 823.80 & $6 / 20 / 2006$ \\
\hline 37.525 & 94.003 & NA & 1,053 & 560 & 335.90 & 717.10 & $3 / 17 / 2006$ \\
\hline 37.521 & 93.935 & NA & 1,040 & 445 & 328.80 & 711.20 & $3 / 15 / 2006$ \\
\hline 37.333 & 94.045 & 30N28W20BBB & 1,119 & 1,153 & 201.00 & 916.00 & $3 / 15 / 2006$ \\
\hline \multicolumn{8}{|c|}{ Greene County, Missouri } \\
\hline 37.114 & 93.455 & 28N23W21CDA & 1,281 & 1,195 & 338.00 & 943.00 & $6 / 14 / 2006$ \\
\hline 37.129 & 93.497 & 28N23W18CCB & 1,270 & 500 & 273.00 & 997.00 & $6 / 14 / 2006$ \\
\hline 37.306 & 93.428 & 30N23W26ABA & 1,240 & 1,130 & 302.00 & 938.00 & $6 / 14 / 2006$ \\
\hline 37.340 & 93.564 & 30N24W10CDB & 1,090 & 565 & 123.60 & 966.40 & $6 / 16 / 2006$ \\
\hline 37.412 & 93.548 & 31N24W14CCC & 1,212 & 1,162 & 96.00 & $1,116.00$ & $6 / 13 / 2006$ \\
\hline \multicolumn{8}{|c|}{ Jasper County, Missouri } \\
\hline 37.155 & 94.438 & 28N32W17AAA & 1,011 & 1,112 & 198.00 & 811.00 & $3 / 09 / 2006$ \\
\hline 37.188 & 94.561 & 29N33W32CCD & 920 & 1,475 & 220.80 & 699.20 & $3 / 09 / 2006$ \\
\hline 37.154 & 94.547 & 28N33W17ADD & 936 & 1,600 & 102.00 & 832.00 & $3 / 09 / 2006$ \\
\hline 37.177 & 94.287 & 28N31W02CBA & 955 & 1,825 & 339.00 & 616.00 & $3 / 09 / 2006$ \\
\hline 37.242 & 94.436 & 29N32W17AAA & 964 & 1,100 & 225.10 & 738.90 & $3 / 10 / 2006$ \\
\hline
\end{tabular}


Appendix 2. Information pertaining to wells completed in the Ozark aquifer.-Continued

[Horizontal datum is North American Datum of 1983 (NAD 83); Vertical datum is National Geodetic Vertical Datum of 1929 (NGVD 29); NA, not available; *, well completed in the Springfield and Ozark aquifers]

\begin{tabular}{|c|c|c|c|c|c|c|c|}
\hline $\begin{array}{l}\text { Latitude } \\
\text { (decimal } \\
\text { degrees) }\end{array}$ & $\begin{array}{c}\text { Longitude } \\
\text { (decimal } \\
\text { degrees) }\end{array}$ & Station name & $\begin{array}{l}\text { Land- surface } \\
\text { altitude } \\
\text { (feet above } \\
\text { NGVD of 1929) }\end{array}$ & $\begin{array}{c}\text { Well depth } \\
\text { (feet below } \\
\text { land } \\
\text { surface) }\end{array}$ & $\begin{array}{l}\text { Depth to } \\
\text { water } \\
\text { (feet below } \\
\text { land } \\
\text { surface) }\end{array}$ & $\begin{array}{c}\text { Water-level } \\
\text { altitude } \\
\text { (feet above } \\
\text { NGVD of 1929) }\end{array}$ & $\begin{array}{c}\text { Date of } \\
\text { measurement }\end{array}$ \\
\hline \multicolumn{8}{|c|}{ Jasper County, Missouri-Continued } \\
\hline 37.100 & 94.376 & NA & 970 & 1,747 & 20.57 & 949.43 & $3 / 08 / 2006$ \\
\hline 37.060 & 94.405 & NA & 1,102 & 1,445 & 464.00 & 638.00 & $3 / 09 / 2006$ \\
\hline 37.073 & 94.472 & NA & 1,098 & 1,500 & 521.00 & 577.00 & $3 / 09 / 2006$ \\
\hline \multicolumn{8}{|c|}{ Lawrence County, Missouri } \\
\hline 36.928 & 93.797 & 26N26W29DCD & 1,402 & 715 & 122.30 & $1,279.70$ & $3 / 14 / 2006$ \\
\hline 36.946 & 94.003 & 26N28W21CCD & 1,207 & 1,195 & 110.50 & $1,096.50$ & $3 / 14 / 2006$ \\
\hline 37.102 & 93.944 & 28N28W36BAC & 1,193 & 1,300 & 101.80 & $1,091.20$ & $3 / 14 / 2006$ \\
\hline 37.021 & 93.897 & 27N27W28CBB & 1,335 & 932 & 231.40 & $1,103.60$ & $3 / 14 / 2006$ \\
\hline 37.214 & 93.945 & 29N28W24BCB & 1,238 & 1,250 & 169.00 & $1,069.00$ & $3 / 14 / 2006$ \\
\hline 37.113 & 93.823 & 28N26W30BBC & 1,240 & 1,108 & 216.50 & $1,023.50$ & $3 / 15 / 2006$ \\
\hline 37.047 & 93.783 & 27N26W16CDB & 1,202 & 410 & 76.50 & $1,125.50$ & $3 / 15 / 2006$ \\
\hline 37.215 & 93.836 & 29N27W24BBD & 1,300 & 1,076 & 221.40 & $1,078.60$ & $3 / 15 / 2006$ \\
\hline 37.007 & 93.723 & 27N26W36ACD* & 1,320 & 400 & 207.30 & $1,112.70$ & $3 / 15 / 2006$ \\
\hline 37.201 & 93.689 & NA & 1,040 & NA & 0.00 & $1,040.00$ & $3 / 14 / 2006$ \\
\hline 37.167 & 93.702 & 28N25W06ADC & 1,233 & 530 & 113.20 & $1,119.80$ & $6 / 21 / 2006$ \\
\hline \multicolumn{8}{|c|}{ McDonald County, Missouri } \\
\hline 36.559 & 94.485 & 21N33W10DCD & 960 & 1,240 & 371.20 & 586.00 & $3 / 07 / 2006$ \\
\hline 36.553 & 94.486 & 21N33W15ACC & 845 & 800 & 364.20 & 480.80 & $3 / 07 / 2006$ \\
\hline 36.547 & 94.493 & $21 \mathrm{~N} 33 \mathrm{~W} 15 \mathrm{DC}$ & 992 & 1,113 & 344.25 & 645.00 & $3 / 07 / 2006$ \\
\hline 36.555 & 94.488 & $21 \mathrm{~N} 33 \mathrm{~W} 15 \mathrm{AC}$ & 895 & 1,110 & 463.64 & 431.36 & $3 / 07 / 2006$ \\
\hline 36.543 & 94.484 & 21N33W22AAA & 830 & 850 & 365.10 & 464.90 & $3 / 07 / 2006$ \\
\hline 36.539 & 94.465 & 21N33W23ADD & 875 & 661 & 338.75 & 536.25 & $3 / 07 / 2006$ \\
\hline 36.544 & 94.184 & 21N30W16ACC & 1,457 & 1,575 & 507.72 & 807.00 & $3 / 07 / 2006$ \\
\hline 36.619 & 94.286 & 22N31W21ACA* & 900 & 85 & 17.40 & 882.60 & $3 / 07 / 2006$ \\
\hline 36.506 & 94.246 & $21 \mathrm{~N} 31 \mathrm{~W} 36 \mathrm{BBB} *$ & 1,024 & 100 & 27.80 & 996.20 & $3 / 07 / 2006$ \\
\hline 36.742 & 94.429 & NA & 1,168 & 500 & 301.55 & 866.45 & $3 / 06 / 2006$ \\
\hline 36.539 & 94.466 & NA & 875 & 382 & 316.90 & 558.10 & $3 / 07 / 2006$ \\
\hline 36.592 & 94.450 & NA & 940 & 420 & 273.30 & 666.70 & $3 / 07 / 2006$ \\
\hline 36.555 & 94.169 & NA & 1,440 & 1,500 & 600.00 & 840.00 & $3 / 07 / 2006$ \\
\hline 36.547 & 94.315 & NA & 1,209 & 1,220 & 405.00 & 804.00 & $3 / 07 / 2006$ \\
\hline 36.501 & 94.259 & NA & 1,148 & 1,750 & 285.00 & 863.00 & $3 / 07 / 2006$ \\
\hline 36.651 & 94.580 & NA & 970 & 900 & 331.00 & 639.00 & $3 / 07 / 2006$ \\
\hline \multicolumn{8}{|c|}{ Newton County, Missouri } \\
\hline 36.873 & 94.369 & 25N31W19BCC & 988 & 1,210 & 190.00 & 798.00 & $3 / 06 / 2006$ \\
\hline 36.790 & 94.446 & 24N33W24CDC & 1,190 & 410 & 325.30 & 864.70 & $3 / 06 / 2006$ \\
\hline
\end{tabular}


Appendix 2. Information pertaining to wells completed in the Ozark aquifer-Continued

[Horizontal datum is North American Datum of 1983 (NAD 83); Vertical datum is National Geodetic Vertical Datum of 1929 (NGVD 29); NA, not available; *, well completed in the Springfield and Ozark aquifers]

\begin{tabular}{|c|c|c|c|c|c|c|c|}
\hline $\begin{array}{l}\text { Latitude } \\
\text { (decimal } \\
\text { degrees) }\end{array}$ & $\begin{array}{c}\text { Longitude } \\
\text { (decimal } \\
\text { degrees) }\end{array}$ & Station name & $\begin{array}{l}\text { Land- surface } \\
\text { altitude } \\
\text { (feet above } \\
\text { NGVD of 1929) }\end{array}$ & $\begin{array}{c}\text { Well depth } \\
\text { (feet below } \\
\text { land } \\
\text { surface) }\end{array}$ & $\begin{array}{l}\text { Depth to } \\
\text { water } \\
\text { (feet below } \\
\text { land } \\
\text { surface) }\end{array}$ & $\begin{array}{c}\text { Water-level } \\
\text { altitude } \\
\text { (feet above } \\
\text { NGVD of 1929) }\end{array}$ & $\begin{array}{c}\text { Date of } \\
\text { measurement }\end{array}$ \\
\hline \multicolumn{8}{|c|}{ Newton County, Missouri-Continued } \\
\hline 37.000 & 94.491 & 26N32W10CAC* & 1,070 & 425 & 176.10 & 893.90 & $3 / 07 / 2006$ \\
\hline 37.012 & 94.520 & 27N33W34DCD* & 975 & 384 & 65.10 & 909.90 & $3 / 07 / 2006$ \\
\hline 36.774 & 94.358 & $24 \mathrm{~N} 32 \mathrm{~W} 26 \mathrm{CCA}^{*}$ & 1,095 & 525 & 161.10 & 933.90 & $3 / 07 / 2006$ \\
\hline 36.988 & 94.446 & 26N32W08DAA* & 1,000 & 520 & 144.10 & 855.90 & $3 / 10 / 2006$ \\
\hline 36.818 & 94.090 & 24N29W08BBD & 1,285 & 1,070 & 190.00 & $1,095.00$ & $3 / 08 / 2006$ \\
\hline 36.761 & 94.192 & NA & 1,130 & 950 & 211.00 & 919.00 & $3 / 08 / 2006$ \\
\hline 36.835 & 94.605 & 24N34W09BDB & 940 & 1,456 & 290.40 & 649.60 & $3 / 08 / 2006$ \\
\hline 36.843 & 94.615 & 25N34W35DBC & 991 & 1,279 & 344.30 & 646.70 & $3 / 08 / 2006$ \\
\hline 36.945 & 94.516 & 26N33W26CBB & 1,185 & 1,580 & 313.00 & 872.00 & $3 / 16 / 2006$ \\
\hline 37.046 & 94.387 & NA & 1,126 & 1,500 & 304.00 & 822.00 & $3 / 09 / 2006$ \\
\hline 37.032 & 94.369 & NA & 1,126 & 1,495 & 218.00 & 908.00 & $3 / 09 / 2006$ \\
\hline 37.054 & 94.363 & NA & 1,126 & 1,518 & 304.00 & 822.00 & $3 / 09 / 2006$ \\
\hline \multicolumn{8}{|c|}{ Polk County, Missouri } \\
\hline 37.457 & 93.501 & 32N24W31CAD & 1,040 & 650 & 247.20 & 792.80 & $6 / 15 / 2006$ \\
\hline 37.599 & 93.442 & 33N23W10CDC & 1,129 & 1,195 & 318.00 & 811.00 & $6 / 15 / 2006$ \\
\hline 37.603 & 93.435 & 33N23W10DAC & 1,120 & 1,200 & 170.00 & 950.00 & $6 / 15 / 2006$ \\
\hline \multicolumn{8}{|c|}{ Vernon County, Missouri } \\
\hline 37.706 & 94.317 & 34N31W10DCC & 927 & 950 & 291.00 & 633.00 & $3 / 16 / 2006$ \\
\hline 37.660 & 94.182 & 34N30W26DDD & 985 & 1,115 & 265.00 & 718.00 & $3 / 16 / 2006$ \\
\hline 37.798 & 94.164 & 35N30W19ADA & 890 & 900 & 213.00 & 674.00 & $3 / 16 / 2006$ \\
\hline 38.018 & 94.115 & 38N29W33DDD & 758 & 750 & 37.35 & 720.65 & $3 / 16 / 2006$ \\
\hline 37.794 & 94.168 & 35N30W19DBA* & 890 & 800 & 195.00 & 695.00 & $3 / 16 / 2006$ \\
\hline 37.899 & 94.231 & 30N36W15BCC* & 855 & 840 & 147.00 & 706.00 & $3 / 16 / 2006$ \\
\hline 37.659 & 94.298 & 34N31W35ABD* & 912 & 850 & 212.50 & 697.00 & $3 / 17 / 2006$ \\
\hline \multicolumn{8}{|c|}{ Stone County, Missouri } \\
\hline 36.810 & 93.458 & 24N23W06DBB & 1,155 & 500 & 239.10 & 915.90 & $6 / 20 / 2006$ \\
\hline 36.896 & 93.516 & 25N24W01CAC3 & 1,075 & 200 & 12.80 & $1,062.20$ & $6 / 20 / 2006$ \\
\hline 36.902 & 93.513 & 25N24W01ACB & 1,205 & 387 & 146.10 & $1,058.90$ & $6 / 20 / 2006$ \\
\hline 36.926 & 93.501 & $26 \mathrm{~N} 23 \mathrm{~W} 30 \mathrm{CBC}$ & 1,152 & 550 & 68.50 & $1,083.50$ & $6 / 15 / 2005$ \\
\hline 37.065 & 93.557 & 27N24W09AAD & 1,362 & $1,, 190$ & 158.00 & $1,204.00$ & $6 / 15 / 2006$ \\
\hline \multicolumn{8}{|c|}{ Craig County, Oklahoma } \\
\hline 36.878 & 95.088 & 28N21E29 & 830 & 600 & 165.05 & 664.95 & $3 / 24 / 2006$ \\
\hline 36.879 & 95.088 & 28N21E29 & 830 & 1,200 & 172.75 & 657.25 & $3 / 24 / 2006$ \\
\hline 36.802 & 95.077 & 27N21E20 & 795 & 1,045 & 296.87 & 498.13 & $3 / 24 / 2006$ \\
\hline 36.838 & 95.119 & 27N20E12 & 890 & 688 & 211.96 & 678.04 & $3 / 23 / 2006$ \\
\hline
\end{tabular}




\section{Potentiometric Surfaces in the Springfield Plateau and Ozark Aquifers}

Appendix 2. Information pertaining to wells completed in the Ozark aquifer.-Continued

[Horizontal datum is North American Datum of 1983 (NAD 83); Vertical datum is National Geodetic Vertical Datum of 1929 (NGVD 29); NA, not available; *, well completed in the Springfield and Ozark aquifers]

\begin{tabular}{|c|c|c|c|c|c|c|c|}
\hline $\begin{array}{l}\text { Latitude } \\
\text { (decimal } \\
\text { degrees) }\end{array}$ & $\begin{array}{l}\text { Longitude } \\
\text { (decimal } \\
\text { degrees) }\end{array}$ & Station name & $\begin{array}{l}\text { Land- surface } \\
\text { altitude } \\
\text { (feet above } \\
\text { NGVD of 1929) }\end{array}$ & $\begin{array}{l}\text { Well depth } \\
\text { (feet below } \\
\text { land } \\
\text { surface) }\end{array}$ & $\begin{array}{l}\text { Depth to } \\
\text { water } \\
\text { (feet below } \\
\text { land } \\
\text { surface) }\end{array}$ & $\begin{array}{l}\text { Water-level } \\
\text { altitude } \\
\text { (feet above } \\
\text { NGVD of 1929) }\end{array}$ & $\begin{array}{c}\text { Date of } \\
\text { measurement }\end{array}$ \\
\hline \multicolumn{8}{|c|}{ Craig County, Oklahoma-Continued } \\
\hline 36.839 & 95.119 & 27N20E12 & 900 & 1,091 & 205.76 & 694.24 & $3 / 23 / 2006$ \\
\hline 36.635 & 95.057 & $25 \mathrm{~N} 21 \mathrm{E} 21$ & 770 & 487 & 108.84 & 661.16 & $3 / 23 / 2006$ \\
\hline 36.627 & 95.018 & 25N21E23 & 760 & 600 & 103.74 & 656.26 & $3 / 23 / 2006$ \\
\hline 36.677 & 95.160 & $25 \mathrm{~N} 20 \mathrm{E} 03$ & 700 & 600 & 28.35 & 671.65 & $3 / 23 / 2006$ \\
\hline 36.690 & 95.108 & 26N20E36 & 740 & 770 & 72.80 & 667.20 & $3 / 23 / 2006$ \\
\hline 36.621 & 95.001 & 25N21E25 & 815 & 720 & 102.70 & 712.30 & $3 / 15 / 2006$ \\
\hline 36.904 & 95.030 & $28 \mathrm{~N} 21 \mathrm{E} 14$ & 860 & NA & 92.90 & 767.10 & $3 / 29 / 2006$ \\
\hline \multicolumn{8}{|c|}{ Delaware County, Oklahoma } \\
\hline 36.377 & 94.938 & 22N22E22 & 760 & 210 & 30.38 & 729.62 & $3 / 23 / 2006$ \\
\hline 36.406 & 94.825 & 22N23E11 & 1,074 & 1,442 & 267.52 & 806.48 & $3 / 21 / 2006$ \\
\hline 36.586 & 94.779 & 24N24E06 & 840 & 975 & 143.52 & 696.48 & $3 / 23 / 2006$ \\
\hline 36.425 & 94.632 & $23 \mathrm{~N} 25 \mathrm{E} 33$ & 1,080 & 1,160 & 61.04 & $1,018.96$ & 3/30/2006 \\
\hline 36.263 & 94.683 & NA & 1,200 & 1,790 & 380.00 & 820.00 & 6/01/2006 \\
\hline \multicolumn{8}{|c|}{ Ottawa County, Oklahoma } \\
\hline 36.839 & 94.748 & 27N24E08 & 830 & 1,030 & 159.60 & 670.40 & $3 / 23 / 2006$ \\
\hline 36.972 & 94.868 & 29N22E25 & 830 & 1,030 & 138.00 & 692.00 & $3 / 23 / 2006$ \\
\hline 36.693 & 94.966 & 26N22E32 & 780 & 991 & 128.27 & 651.73 & $3 / 23 / 2006$ \\
\hline 36.875 & 94.867 & 28N23E30 & 770 & 1,490 & 379.84 & 390.16 & $3 / 23 / 2006$ \\
\hline 36.943 & 94.798 & 28N23E02 & 840 & NA & 390.35 & 449.65 & $3 / 23 / 2006$ \\
\hline
\end{tabular}


Appendix 3. Information pertaining to springs in the Springfield Plateau aquifer.

[Horizontal datum is North American Datum of 1983 (NAD 83); Vertical datum is National Geodetic Vertical datum of 1929 (NGVD 29]

\begin{tabular}{|c|c|c|c|c|c|}
\hline $\begin{array}{l}\text { Latitude } \\
\text { (decimal } \\
\text { degrees) }\end{array}$ & $\begin{array}{c}\text { Longitude } \\
\text { (decimal } \\
\text { degrees) }\end{array}$ & $\begin{array}{c}\text { Water-level } \\
\text { altitude } \\
\text { (feet above } \\
\text { NGVD of 1929) }\end{array}$ & $\begin{array}{l}\text { Latitude } \\
\text { (decimal } \\
\text { degrees) }\end{array}$ & $\begin{array}{l}\text { Longitude } \\
\text { (decimal } \\
\text { degrees) }\end{array}$ & $\begin{array}{c}\text { Water-level } \\
\text { altitude } \\
\text { (feet above } \\
\text { NGVD of 1929) }\end{array}$ \\
\hline \multicolumn{3}{|c|}{ Benton County, Arkansas } & \multicolumn{3}{|c|}{ Washington County, Arkansas-Continued } \\
\hline 36.453 & 94.164 & 1,210 & 36.151 & 94.240 & 1,195 \\
\hline 36.198 & 94.393 & 1,060 & 36.151 & 94.240 & 1,195 \\
\hline 36.220 & 94.446 & 1,120 & 36.151 & 94.293 & 1,160 \\
\hline 36.242 & 94.216 & 1,150 & 36.154 & 94.225 & 1,180 \\
\hline 36.259 & 94.257 & 1,145 & 36.163 & 94.225 & 1,195 \\
\hline 36.261 & 94.219 & 1,100 & 36.172 & 94.085 & 1,320 \\
\hline 36.262 & 94.420 & 1,200 & 36.199 & 94.323 & 1,090 \\
\hline 36.264 & 93.974 & 1,280 & 36.206 & 94.235 & 1,150 \\
\hline 36.283 & 94.276 & 1,138 & 36.206 & 94.235 & 1,150 \\
\hline 36.298 & 93.958 & 1,160 & 36.214 & 94.155 & 1,225 \\
\hline 36.297 & 94.395 & 1,300 & \multicolumn{3}{|c|}{ Barry County, Missouri } \\
\hline 36.300 & 94.300 & 1,200 & 36.650 & 93.896 & 1,360 \\
\hline 36.301 & 94.300 & 1,198 & 36.669 & 93.850 & 1,360 \\
\hline 36.303 & 94.391 & 1,330 & 36.685 & 93.956 & 1,450 \\
\hline 36.305 & 94.390 & 1,330 & 36.740 & 93.836 & 1,250 \\
\hline 36.310 & 94.279 & 1,170 & 36.773 & 94.014 & 1,280 \\
\hline 36.331 & 94.455 & 1,250 & 36.783 & 94.032 & 1,250 \\
\hline 36.354 & 94.433 & 1,200 & 36.797 & 93.959 & 1,350 \\
\hline 36.357 & 94.286 & 1,259 & 36.830 & 94.047 & 1,200 \\
\hline 36.389 & 94.389 & 1,058 & 36.835 & 94.056 & 1,210 \\
\hline 36.395 & 94.117 & 1,190 & 36.859 & 94.049 & 1,180 \\
\hline 36.399 & 94.425 & 1,100 & 36.883 & 94.005 & 1,230 \\
\hline 36.406 & 94.557 & 1,120 & 36.896 & 94.059 & 1,160 \\
\hline 36.420 & 94.082 & 1,190 & 36.898 & 94.059 & 1,152 \\
\hline 36.441 & 94.071 & 1,340 & \multicolumn{3}{|c|}{ Cedar County, Missouri } \\
\hline 36.446 & 94.223 & 1,085 & 37.594 & 93.905 & 945 \\
\hline 36.453 & 94.164 & 1,210 & 37.700 & 93.796 & 912 \\
\hline 36.440 & 94.036 & 1,386 & \multicolumn{3}{|c|}{ Dade County, Missouri } \\
\hline \multicolumn{3}{|c|}{ Washington County, Arkansas } & 37.296 & 93.645 & 1,090 \\
\hline 36.076 & 94.465 & 1,040 & 37.329 & 93.825 & 1,002 \\
\hline 36.105 & 94.383 & 1,200 & 37.330 & 93.825 & 1,005 \\
\hline 36.126 & 94.229 & 1,125 & 37.403 & 93.881 & 1,080 \\
\hline 36.126 & 94.225 & 1,140 & 37.551 & 93.660 & 920 \\
\hline 36.136 & 94.203 & 1,150 & 37.561 & 93.718 & 908 \\
\hline 36.136 & 94.203 & 1,150 & \multicolumn{3}{|c|}{ Jasper County, Missouri } \\
\hline 36.144 & 94.175 & 1,250 & 37.092 & 94.459 & 990 \\
\hline 36.146 & 94.180 & 1,292 & 37.150 & 94.525 & 900 \\
\hline
\end{tabular}




\section{$24 \quad$ Potentiometric Surfaces in the Springfield Plateau and Ozark Aquifers}

Appendix 3. Information pertaining to springs in the Springfield Plateau aquifer-Continued

[Horizontal datum is North American Datum of 1983 (NAD 83); Vertical datum is National Geodetic Vertical datum of 1929 (NGVD 29]

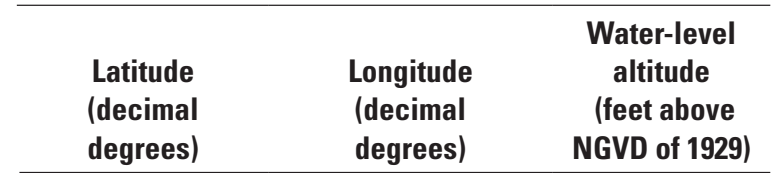

Jasper County, Missouri-Continued

$\begin{array}{rrr}37.155 & 94.187 & 1,000 \\ 37.163 & 94.513 & 900 \\ 37.222 & 94.401 & 900\end{array}$

Lawrence County, Missouri

$\begin{array}{rrr}36.947 & 94.007 & 1,200 \\ 36.958 & 93.802 & 1,300 \\ 37.038 & 93.654 & 1,285 \\ 37.038 & 93.654 & 1,290 \\ 37.049 & 94.007 & 1,170 \\ 37.111 & 93.880 & 1,130 \\ 37.136 & 93.708 & 1,220 \\ 37.177 & 93.731 & 1,130 \\ 37.244 & 93.632 & 1,120 \\ 37.246 & 93.729 & 990 \\ 36.964 & 93.611 & 1,260 \\ & \text { McDonald County, Missouri } \\ 36.656 & 94.445 & 900 \\ 36.657 & 94.501 & 1,020 \\ 36.718 & 94.422 & 1,080\end{array}$

Newton County, Missouri

36.807

36.815

36.817

36.853

36.864

36.870

36.874

36.946

36.990

37.004

37.021

37.030

37.031

37.031

36.027

36.033
$94.149 \quad 1,160$

$94.324 \quad 1,180$

$94.320 \quad 1,180$

94.320

94.369

94.372

94.369

94.443

94.431

94.458

94.468

94.520

94.086

94.521

Adair County, Oklahoma

94.721

94.727
900

200

300

290

170

130

220

120

990

260

900

, 080

1,100

1,040

1,040

1,020

995

960

930

940

900

1,150

890

950

930

\begin{tabular}{ccc}
\hline & Water-level \\
Latitude & Longitude & altitude \\
(decimal & (decimal & (feet above \\
degrees) & degrees) & NGVD of 1929) \\
\hline
\end{tabular}

Adair County, Oklahoma-Continued

36.062

36.071

94.776

1,080

36.088

94.681

1,050

36.089

94.593

1,000

36.096

94.600

1,100

94.649

1,050

36.123

94.661

1,100

36.125

94.703

1,000

94.653

950

36.140

94.657

1,000

36.145

94.663

939

Delaware County, Oklahoma

36.172

94.590

1,100

36.546

94.622

950

36.546

94.650

880

36.174

94.668

1,030

36.177

94.803

1,030

36.203

94.750

1,000

36.208

94.867

1,100

36.210

94.704

1,000

94.617

1,000

36.238

94.666

1,000

94.725

1,050

94.663

1,000

36.276

36.411

94.789

900

94.975

800

94.650

1,100

Mayes County, Oklahoma

36.192

95.092

850

36.197

95.149

850

36.261

95.006

700

36.281

95.053

800

36.311

95.009

700

36.464

95.031

660

Ottawa County, Oklahoma

$\begin{array}{lll}36.783 & 94.648 & 845\end{array}$

36.828

94.717

823 
Appendix 4. Information pertaining to springs in the Ozark aquifer.

[Horizontal datum is North American Datum of 1983 (NAD 83); Vertical datum is National Geodetic Vertical Datum of 1929 (NGVD 29)]

\begin{tabular}{ccc}
\hline $\begin{array}{c}\text { Latitude } \\
\text { (decimal } \\
\text { degrees) }\end{array}$ & $\begin{array}{c}\text { Water-level } \\
\text { altitude } \\
\text { (feet above } \\
\text { NGVD of 1929) }\end{array}$ \\
\hline 36.484 & Benton County, Arkansas \\
36.489 & 94.458 & 900 \\
& 94.471 & 900 \\
36.592 & Barry County, Missouri & 1,045 \\
37.117 & 93.833 & 1,180 \\
\hline
\end{tabular}


Publishing support provided by: Lafayette Publishing Service Center

For more information concerning the research described in the report:

U.S. Geological Survey Arkansas Water Science Center 401 Hardin Road Little Rock, AR 72211-3528

(501) 228-3600

http://ar.water.usgs.gov 


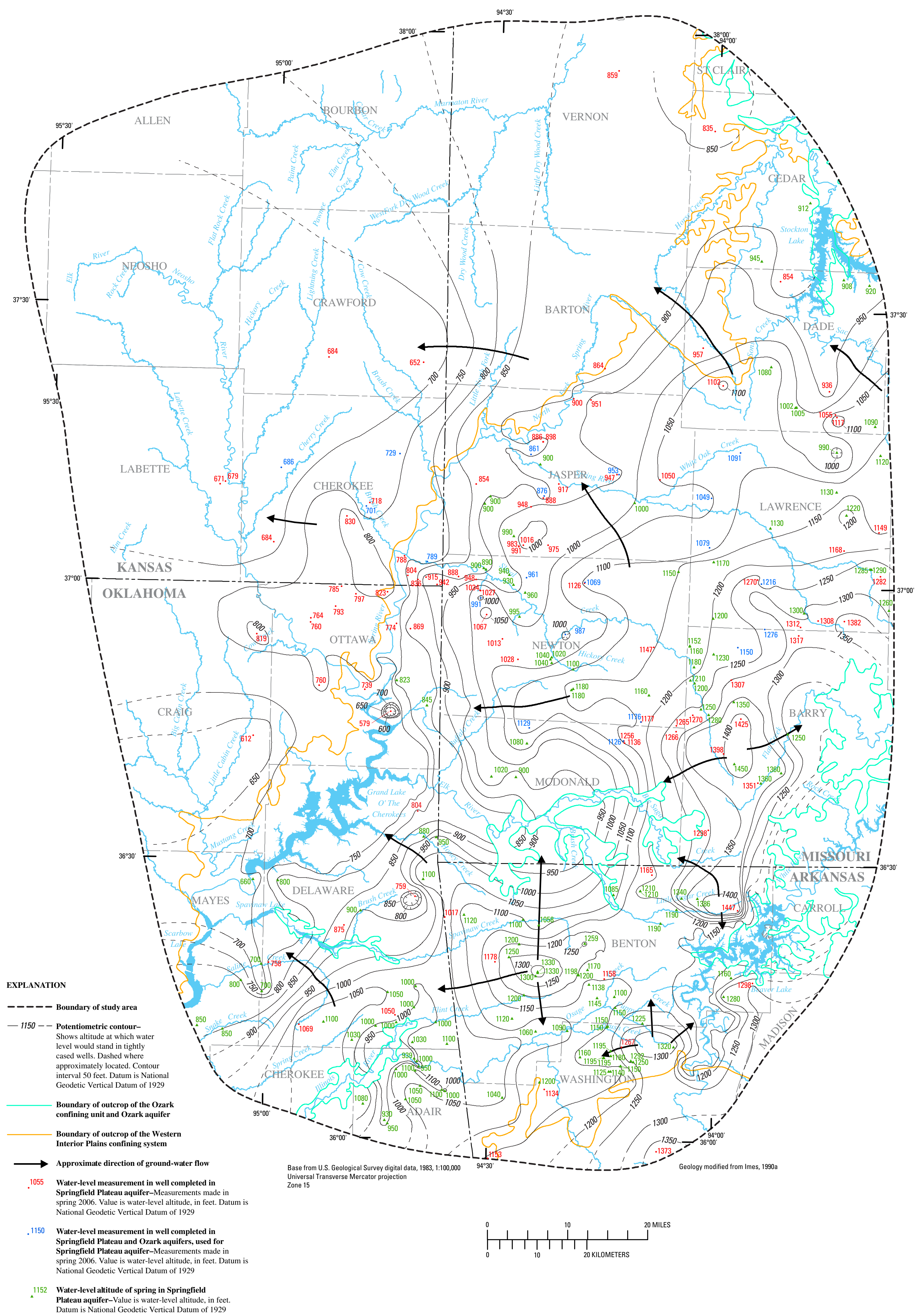

Potentiometric Surface of the Springfield Plateau Aquifer in Northwestern Arkansas, Southeastern Kansas, Southwestern Missouri, and Northeastern Oklahoma, 2006 


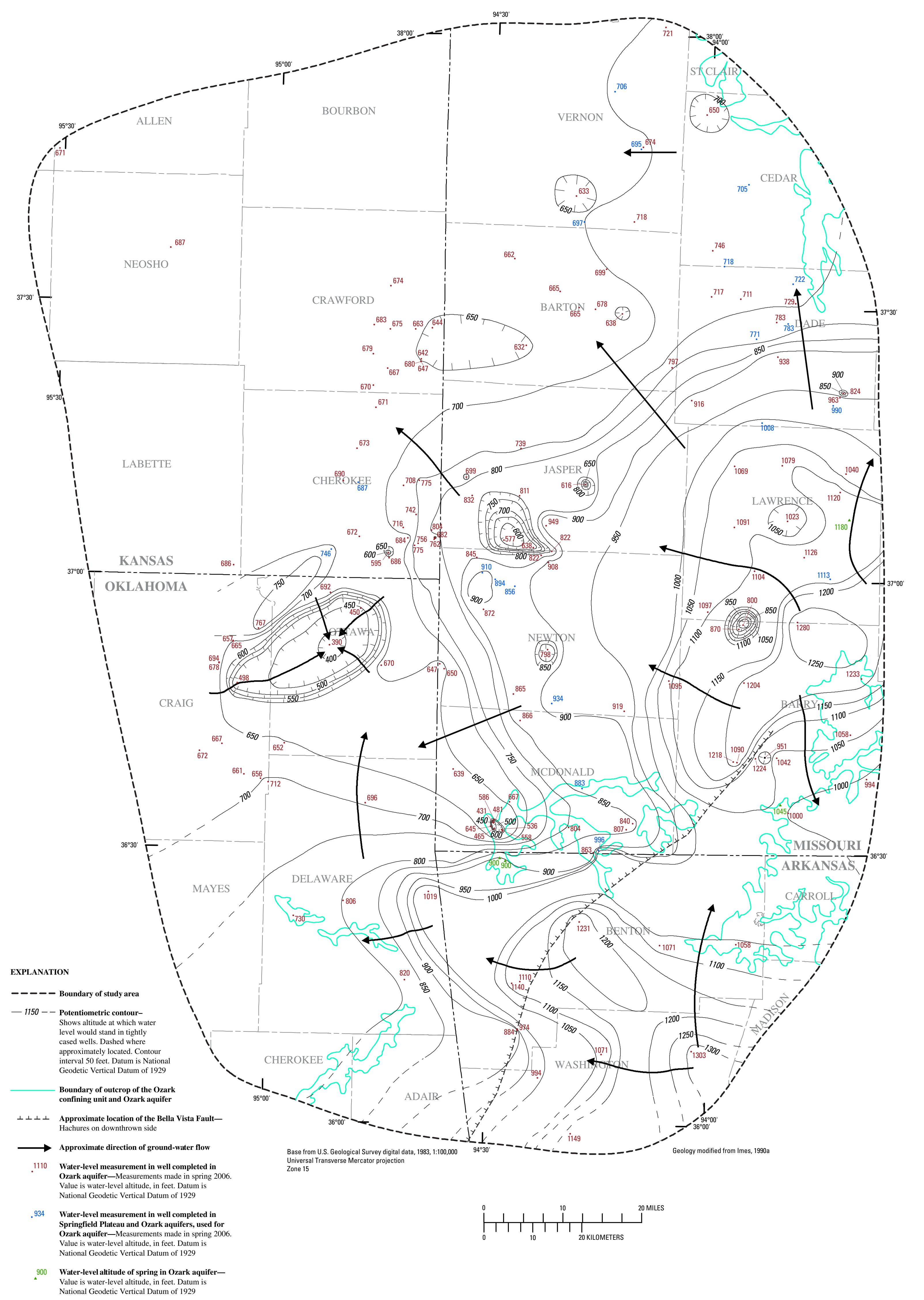

Potentiometric Surface of the Ozark Aquifer in Northwestern Arkansas, Southeastern Kansas, Southwestern Missouri, and Northeastern Oklahoma, 2006 


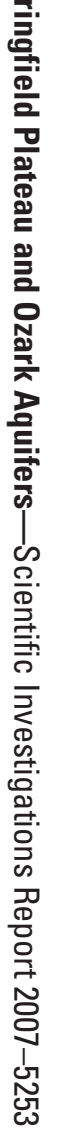

8 Printed on recycled paper 